\title{
Total Syntheses of Clausamines A-C and Clausevatine D
}

\author{
Supporting Information \\ Terry P. Lebold and Michael A. Kerr* \\ The University of Western Ontario, Department of Chemistry, \\ London, Ontario, Canada N6A 5B7
}

\section{Table of Contents}

General Experimental

Experimental procedures and characterization data Spectra page $\mathrm{S}-2$

page $\mathrm{S}-2-\mathrm{S}-14$

page $\mathrm{S}-15-\mathrm{S}-48$ 


\section{Experimental}

\section{General}

Melting points were determined using a Gallenkamp melting point apparatus and are uncorrected. Infrared spectra were obtained as thin films on $\mathrm{NaCl}$ plates using a Bruker Vector 33 FT-IR instrument. NMR experiments were performed on Varian Mercury 400, Varian Inova 600 and Inova 400 instruments and samples were obtained in $\mathrm{CDCl}_{3}$ (referenced to $7.26 \mathrm{ppm}$ for ${ }^{1} \mathrm{H}$ and 77.0 for ${ }^{13} \mathrm{C}$ ), acetone- $\mathrm{d}_{6}$ (referenced to $2.05 \mathrm{ppm}$ for ${ }^{1} \mathrm{H}$ and 29.8 for ${ }^{13} \mathrm{C}$ ), or DMSO- $\mathrm{d}_{6}$ (referenced to 2.50 for ${ }^{1} \mathrm{H}$ and 29.8 for ${ }^{13} \mathrm{C}$ ) . Coupling constants $(\mathrm{J})$ are in Hz. The multiplicities of the signals are described using the following abbreviations: $\mathrm{s}=$ singlet, $\mathrm{d}=$ doublet, $\mathrm{t}=$ triplet, $\mathrm{q}=$ quartet, $\mathrm{m}=$ multiplet, $\mathrm{br}=$ broad. High resolution mass spectra (HRMS) were obtained on a Finnigan MAT 8200 spectrometer at $70 \mathrm{eV}$. Optical rotations were recorded in cells of $10 \mathrm{~cm}$ path length using a Perkin-Elmer 241 digital polarimeter in either $\mathrm{CHCl}_{3}$ or $\mathrm{MeOH}$ at $23{ }^{\circ} \mathrm{C}$.

Tetrahydrofuran (THF), dioxane, and dichloromethane (DCM) were dried and deoxygenated by passing the nitrogen purged solvents through activated alumina columns. All other reagents and solvents were used as purchased from Aldrich, Strem, Caledon or VWR. Reaction progress was followed by thin layer chromatography (TLC) (EM Science, silica gel $60 \mathrm{~F}_{254}$ ) visualizing with UV light, and the plates developed using acidic anisaldehyde. Flash chromatography was performed using silica gel purchased from Silicycle Chemical Division Inc. (230-400 mesh).

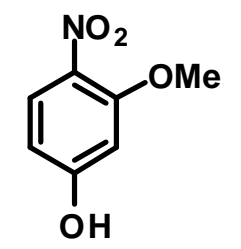

Intermediate A

Fluoro compound 10 (7.100 g, $41.490 \mathrm{mmol}$ ) was dissolved in DMSO (60 ml). $\mathrm{NaOH}(8.123 \mathrm{~g}, 203.075 \mathrm{mmol})$ dissolved in $\mathrm{H}_{2} \mathrm{O}(20 \mathrm{ml})$ was then added and the solution vigorously stirred for 20.5 hours, after which TLC showed complete consumption of the starting material. The reaction was cooled to $0{ }^{\circ} \mathrm{C}$ and acidified with $6 \mathrm{M} \mathrm{HCl}$ and then poured into $5 \% \mathrm{HCl}$ solution and extracted 4 times with ether. The combined organics were washed with $5 \% \mathrm{HCl}$ three times, then brine, and dried with $\mathrm{MgSO}_{4}$. The solvent was removed under reduced pressure to give a crude mixture that was purified by column chromatography on silica gel (ethyl acetate / hexanes as eluent) to yield nitro phenol intermediate A (5.972 g, $35.309 \mathrm{mmol}, 85 \%$ ) as a bright yellow solid: m.p. $=143-145{ }^{\circ} \mathrm{C} ; \mathrm{R}_{\mathrm{f}}=0.44$, $50 \%$ EtOAc in hexanes; ${ }^{1} \mathrm{H}-\mathrm{NMR}(400$ MHz, Acetone- $\left.\mathrm{d}_{6}\right): \delta=7.88(\mathrm{~d}, \mathrm{~J}=9.2 \mathrm{~Hz}, 1 \mathrm{H}), 6.67$ (d, J = 2.2 Hz, 1H), 6.54 (dd, J = 9.2, $2.2 \mathrm{~Hz}, 1 \mathrm{H}), 3.93$ (s, 3H), 3.02 (br.s., $1 \mathrm{H})$; ${ }^{13} \mathrm{C}$ NMR (100 MHz, Acetone- $\mathrm{d}_{6}$ ) $\delta=$ 164.2, 156.7, 128.9, 108.0, 105.4, 101.2, 56.7; IR (thin film): 3358, 3094, 3076, 3055, 3030, 2999, 2955, 1628, 1582, 1516, 1492, 1459, 1432, 1371, 1347, 1313, 1278, 1248, 1210, 1199, 1177, 1168, 1099, 1024, 963, 912, 854, 822, 755; HRMS calc'd for $\mathrm{C}_{7} \mathrm{H}_{7} \mathrm{NO}_{4}=169.0375$, found $=169.0369$. 
The tosylated amino phenol $\mathbf{1 1}$ was prepared in two steps from nitro phenol intermediate A without purification of the aniline intermediate.

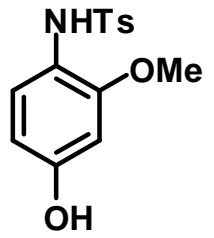

Compound 11

Nitro phenol intermediate A (500 $\mathrm{mg}, 2.956 \mathrm{mmol})$ was dissolved in THF (4 ml) and $\mathrm{MeOH}(16 \mathrm{ml}) .10 \% \mathrm{Pd} / \mathrm{C}(50 \mathrm{mg})$ was added and the reaction put over an atmosphere of $\mathrm{H}_{2}$ and allowed to stir for 4 hours after which TLC showed complete consumption of the starting material. The reaction was filtered through a plug of celite washing with EtOAc and THF. The solvent was removed under reduced pressure to give the crude amine as a purple-blue crystalline solid which was dissolved in pyridine $(20 \mathrm{ml})$ and cooled to $0{ }^{\circ} \mathrm{C}$. TsCl (592 $\left.\mathrm{mg}, 3.105 \mathrm{mmol}\right)$ was then added and the reaction stirred for 14 hours after which TLC showed complete consumption of the starting material. The solvent was removed under reduced pressure to give a crude mixture that was dissolved in EtOAc and poured into $5 \% \mathrm{HCl}$ solution and extracted 3 times with EtOAc. The combined organics were washed with $5 \% \mathrm{HCl}$ two times, water, then brine, and dried with $\mathrm{MgSO}_{4}$. The solvent was removed under reduced pressure to give a crude mixture that was purified by column chromatography on silica gel (methanol / DCM as eluent) to yield tosylated amino phenol 11 (829 mg, $2.826 \mathrm{mmol}, 96 \%$ over two steps) as a light grey solid: m.p. $=144-145^{\circ} \mathrm{C} ; \mathrm{R}_{\mathrm{f}}=0.49,5 \%$ methanol in DCM; ${ }^{1} \mathrm{H}-\mathrm{NMR}\left(600 \mathrm{MHz}\right.$, Acetone- $\mathrm{d}_{6}$ ): $\delta=8.33$ (br.s, 1H), 7.67 (br.s, $1 \mathrm{H}$ ), 7.55 (d, J = $8.1 \mathrm{~Hz}$, 2H), 7.27 (d, J = 8.1 Hz, 2H), 7.22 (d, J = 9.0 Hz, 1H), 6.38 (dd, J = 9.0, $3.0 \mathrm{~Hz}, 1 \mathrm{H}$ ), $6.31(\mathrm{~d}, \mathrm{~J}=3.0 \mathrm{~Hz}, 1 \mathrm{H}), 3.42(\mathrm{~s}, 3 \mathrm{H}), 2.36$ (s, 3H); ${ }^{13} \mathrm{C}$ NMR (100 MHz, Acetone- $\left.\mathrm{d}_{6}\right) \delta=$ 157.5, 154.3, 143.8, 138.5, 129.8, 128.1, 127.3, 118.4, 107.6, 100.1, 55.7, 21.3; IR (thin film): 3425, 3255, 2969, 2940, 2841, 1608, 1511, 1481, 1457, 1443, 1399, 1328, 1306, $1199,1158,1118,1091,1033,955,906,836,813$, 668; HRMS calc'd for $\mathrm{C}_{14} \mathrm{H}_{15} \mathrm{NO}_{4} \mathrm{~S}=$ 293.0722, found $=293.0731$.

Phenol 12 was prepared in two steps from tosylated amino phenol 11 without purification of the imine quinone $\mathbf{8}$ as it was of sufficient purity to be used in the following DielsAlder reaction. However, for authenticative purposes a small amount of imine quinone 8 was recrystallized from benzene to allow full characterization.<smiles>COc1cc(O)c2c(c1N)C1(CCCCC1)CCCC2=CCO</smiles>

Amino phenol 11 (828 mg) was dissolved in DCM (40ml). $\mathrm{NaIO}_{4} / \mathrm{SiO}_{2}\left(6.199 \mathrm{~g}\right.$ of $\left.0.683 \mathrm{mmol} / \mathrm{g} \mathrm{NaIO} / \mathrm{SiO}_{2}, 4.234 \mathrm{mmol}\right)$ was added and the mixture stirred for 1 hour, after which TLC (5\% $\mathrm{MeOH}$ in DCM) showed complete consumption of the starting material. The reaction mixture was then filtered through a cintered glass funnel to remove the $\mathrm{NaIO}_{4} / \mathrm{SiO}_{2}$ washing with EtOAc. The solvent was removed under reduced pressure to give the crude imine quinone $\mathbf{8}$ as an orange-red solid (842 mg). The crude imine quinone 8 and excess diene 7 were dissolved in DCM (30 ml) and the reaction brought to reflux. The reaction was monitored by $\mathrm{H}^{1} \mathrm{NMR}$ and upon dissapearance of the imine quinone [peaks monitored for dissapearance: ${ }^{1} \mathrm{H}-\mathrm{NMR}\left(600 \mathrm{MHz}, \mathrm{CDCl}_{3}\right): \delta=8.10(\mathrm{~d}, \mathrm{~J}=10.2 \mathrm{~Hz}, 1 \mathrm{H})$, 6.57 (dd, $\mathrm{J}=10.2,1.8 \mathrm{~Hz}, 1 \mathrm{H}$ )] the reaction was cooled to room temperature and 30 drops of DBU were added. After 15 minutes of stirring at room temperature NMR 
showed that all of the Diels-Alder adduct had aromatized [peak monitored for dissapearance: ${ }^{1} \mathrm{H}-\mathrm{NMR}\left(600 \mathrm{MHz}, \mathrm{CDCl}_{3}\right): \delta=7.92(\mathrm{~d}, \mathrm{~J}=8.1 \mathrm{~Hz}, 2 \mathrm{H}), 7.36(\mathrm{~d}, \mathrm{~J}=8.1$ $\mathrm{Hz}, 2 \mathrm{H})]$. The reaction mixture was then poured into $5 \% \mathrm{HCl}$ solution and extracted 3 times with DCM The combined organics were washed with brine and dried with $\mathrm{MgSO}_{4}$. The solvent was removed under reduced pressure to give a crude mixture that was purified by column chromatography on silica gel (ethyl acetate / hexanes as eluent) to yield phenol 12 (913 mg, $2.285 \mathrm{mmol}, 81 \%$ over the two steps) as a very light tan solid: m.p. $=207-209{ }^{\circ} \mathrm{C} ; \mathrm{R}_{\mathrm{f}}=0.50,50 \%$ EtOAc in hexane; ${ }^{1} \mathrm{H}-\mathrm{NMR}\left(600 \mathrm{MHz}\right.$, Acetone- $\left.\mathrm{d}_{6}\right)$ : $\delta=8.27$ (br.s, 1H), 7.53 (d, J = 7.5 Hz, 2H), 7.42 (br.s, $1 \mathrm{H}$ ), 7.31 (d, J = $7.5 \mathrm{~Hz}, 2 \mathrm{H}$ ), 6.20 (s, 1H), 5.52 (br.s, 1H), 3.97-3.92 (m, 1H), 3.24-3.10 (m, 2H), 3.07 (s, 3H), 2.512.46 (m, 1H), 2.40 (s, 3H), 2.32 (br.d, J = 12.0 Hz, 1H), 2.03-2.00 (m, 1H), 1.87 (br.d, J = $12.0 \mathrm{~Hz}, 1 \mathrm{H}$ ), 1.78 (br.d, $12.6 \mathrm{~Hz}, 1 \mathrm{H}$ ), 1.61 (tq, J = 13.2, 3.6 Hz, 1H), 1.34 (tq, J = 13.2, $4.2 \mathrm{~Hz}, 1 \mathrm{H}), 1.02$ (dq, J = 13.2, $3.6 \mathrm{~Hz}, 1 \mathrm{H}) ;{ }^{13} \mathrm{C}$ NMR (100 MHz, DMSO-d 6 ) $\delta=155.0$, 154.6, 141.8, 139.9, 139.7, 139.2, 128.7, 126.6, 113.8, 112.9, 112.5, 96.3, 54.2, 38.7, 36.2, 35.9, 29.0, 27.0, 24.4, 20.9; IR (thin film): 3420, 3286, 2926, 2853, 1596, 1497, 1447, 1375, 1341, 1316, 1305, 1222, 1157, 1121, 1092, 1070, 1058, 1032, 1009, 960, 918, 871, 812; HRMS calc'd for $\mathrm{C}_{22} \mathrm{H}_{25} \mathrm{NO}_{4} \mathrm{~S}=399.1504$, found $=399.1499$.
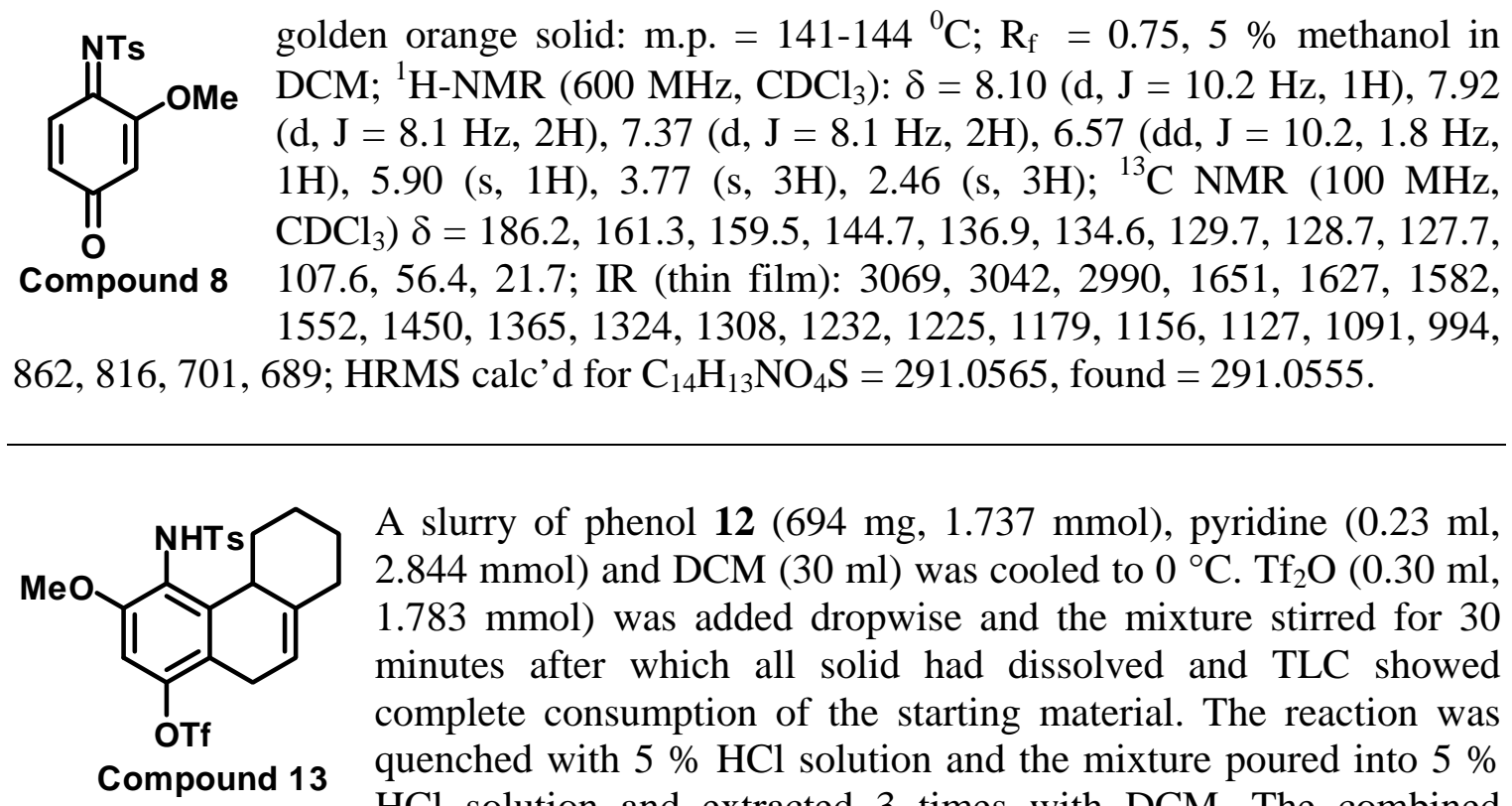

A slurry of phenol 12 (694 mg, $1.737 \mathrm{mmol})$, pyridine $(0.23 \mathrm{ml}$, $2.844 \mathrm{mmol})$ and $\mathrm{DCM}(30 \mathrm{ml})$ was cooled to $0{ }^{\circ} \mathrm{C} . \mathrm{Tf}_{2} \mathrm{O}(0.30 \mathrm{ml}$, $1.783 \mathrm{mmol}$ ) was added dropwise and the mixture stirred for 30 minutes after which all solid had dissolved and TLC showed complete consumption of the starting material. The reaction was quenched with $5 \% \mathrm{HCl}$ solution and the mixture poured into $5 \%$ $\mathrm{HCl}$ solution and extracted 3 times with DCM. The combined organics were washed with brine and dried with $\mathrm{MgSO}_{4}$. The solvent was removed under reduced pressure to yield the crude triflate which was purified by column chromatography on silica gel (EtOAc / hexanes as eluent) to yield triflate $\mathbf{1 3}(0.829 \mathrm{mg}$, $1.556 \mathrm{mmol}, 90 \%$ ) as a very pale yellow solid: m.p. $=152-154{ }^{\circ} \mathrm{C} ; \mathrm{R}_{\mathrm{f}}=0.77,50 \%$ EtOAc in hexane; ${ }^{1} \mathrm{H}-\mathrm{NMR}\left(400 \mathrm{MHz}, \mathrm{CDCl}_{3}\right): \delta=7.53-7.49$ and 7.23-7.20 (m, AA'BB', 4H), 6.46 (s, 1H), 6.09 (s, 1H), 5.49 (t, J = 3.2 Hz, 1H), 4.60 (dq, J = 12.0, 5.4 Hz, 1H), 3.35-3.31 (m, 2H), 3.18 (s, 3H), 2.44-2.37 (m, 4H), 2.36-2.30 (m, 1H), 2.13$2.03(\mathrm{~m}, 1 \mathrm{H}), 1.91-1.77(\mathrm{~m}, 2 \mathrm{H}), 1.65(\mathrm{tq}, \mathrm{J}=12.8,3.6 \mathrm{~Hz}, 1 \mathrm{H}), 1.33$ (tq, $\mathrm{J}=12.8,4.4$ $\mathrm{Hz}, 1 \mathrm{H}), 1.06$ (dq, J = 12.8, $3.6 \mathrm{~Hz}, 1 \mathrm{H}) ;{ }^{13} \mathrm{C}$ NMR $\left(100 \mathrm{MHz}, \mathrm{CDCl}_{3}\right) \delta=153.7,146.7$, 143.6, 142.0, 139.7, 136.6, 128.9, 127.6, 122.1, 120.3, 120.1, 116.9, 111.8, 101.9, 55.1, 38.8, 36.1, 36.0, 29.2, 27.2, 24.6, 21.4; IR (thin film): 3249, 2931, 2854, 1617, 1577, 
1480, 1442, 1420, 1336, 1307, 1246, 1214, 1164, 1141, 1108, 1092, 1040, 1015, 999, 959, 918, 895, 854, 841, 814, 761, 734; HRMS calc'd for $\mathrm{C}_{23} \mathrm{H}_{24} \mathrm{~F}_{3} \mathrm{NO}_{6} \mathrm{~S}_{2}=531.0997$, found $=531.0999$.

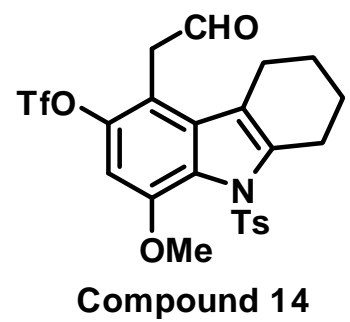

Triflate 13 (1.540 g, $2.897 \mathrm{mmol})$ and NMO (407 mg, $3.474 \mathrm{mmol})$ were dissolved in THF $(20 \mathrm{ml})$ and $\mathrm{H}_{2} \mathrm{O}(5 \mathrm{ml})$. A catalytic amount of $\mathrm{OsO}_{4}$ (a few crystals) was then added and the reaction stirred at room temperature until TLC indicated the complete consumption of the starting material. $\mathrm{Na}_{2} \mathrm{SO}_{3}(1.825 \mathrm{~g}, 14.480$ mmol) dissolved in $\mathrm{H}_{2} \mathrm{O}(10 \mathrm{ml})$ was then added and the solution stirred for 3.5 hours after which the reaction was poured into water and extracted 4 times with ethyl acetate. The combined organics were washed with water then brine, and dried with $\mathrm{MgSO}_{4}$. The solvent was removed under reduced pressure to yield the crude diol as a light tan solid (1.678 g). The diol (1.678 g) was redissolved in DCM $(50 \mathrm{ml})$ and $\mathrm{NaIO}_{4} / \mathrm{SiO}_{2}\left(7.124 \mathrm{~g}\right.$ of $\left.0.61 \mathrm{mmol} / \mathrm{g} \mathrm{NaIO} / 4 \mathrm{SiO}_{2}, 4.346 \mathrm{mmol}\right)$ was added and the mixture stirred for 23 hours, after which TLC showed complete consumption of the diol $\left(\mathrm{R}_{\mathrm{f}}\right.$ of dihydroxyaled product $=0.34,50 \%$ ethyl acetate in hexanes). The reaction mixture was then filtered through a cintered glass funnel, to remove the $\mathrm{NaIO}_{4} / \mathrm{SiO}_{2}$, washing with EtOAc. The solvent was removed under reduced pressure to give a crude residue which was redissolved in THF (25 ml). Concentrated sulfuric acid (6 drops) was then added and the reaction stirred for 2 hours, after which TLC showed only one spot corresponding to aldehyde 14. The solution was then neutralized with $\mathrm{Na}_{2} \mathrm{CO}_{3}$ and $\mathrm{MgSO}_{4}$ was added to remove any water. The reaction mixture was then filtered, washing with EtOAc, and the solvent removed under reduced pressure to yield an off-white foam that was purified by column chromatography on silica gel (EtOAc / hexanes as eluent) to yield aldehyde 14 (1.507 g, $2.762 \mathrm{mmol}, 95 \%$ over 3 steps) as an off-white solid: m.p. $=134-136{ }^{\circ} \mathrm{C}$; $\mathrm{R}_{\mathrm{f}}=0.56$, $33 \%$ EtOAc in hexane; ${ }^{1} \mathrm{H}$ NMR $\left(400 \mathrm{MHz}, \mathrm{CDCl}_{3}\right): \delta=9.76(\mathrm{t}, \mathrm{J}=1.2 \mathrm{~Hz}, 1 \mathrm{H}), 7.74-7.10$ and 7.33-7.29 (m, AA'BB', 4H), 6.59 (s, 1H), 4.07 (d, J = $1.2 \mathrm{~Hz}, 2 \mathrm{H}), 3.60$ (s, 3H), 3.18-3.13 (m, 2H), 2.75-2.71 (m, 2H), $2.43(\mathrm{~s}, 3 \mathrm{H}), 1.89-1.79(\mathrm{~m}, 4 \mathrm{H}) ;{ }^{13} \mathrm{C} \mathrm{NMR}\left(100 \mathrm{MHz}, \mathrm{CDCl}_{3}\right) \delta=$ 197.8, 147.2, 144.1, 143.9, 141.8, 138.8, 132.2, 129.3, 126.3, 125.7, 119.5, 117.4, 109.8, 100.6, 55.7, 41.0, 26.4, 24.1, 22.7, 22.3, 21.5; IR (thin film): 2942, 2847, 2729, 1729, 1621, 1583, 1499, 1419, 1368, 1339, 1316, 1276, 1243, 1214, 1187, 1175, 1140, 1092, 1044, 1003, 980, 964, 932, 875, 830, 733, 663; HRMS calc'd for $\mathrm{C}_{23} \mathrm{H}_{22} \mathrm{~F}_{3} \mathrm{NO}_{7} \mathrm{~S}_{2}=$ 545.0790 , found $=545.0773$. 


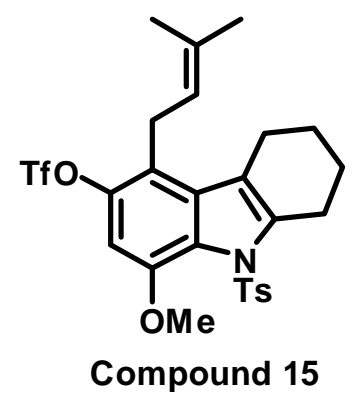

A slurry of isopropyltriphenyl-phosphonium iodide (1.791 g, 4.143 $\mathrm{mmol})$ in THF (15 ml) was cooled to $0{ }^{\circ} \mathrm{C}$. nBuLi $(1.55 \mathrm{ml}$ of 2.5 $\mathrm{M}$ solution in hexanes, $3.875 \mathrm{mmol}$ ) was added dropwise and the solution allowed to stir for 10 minutes producing a dark orange-red solution. Aldehyde 14 (1.507 g, $2.762 \mathrm{mmol})$ was then transferred dropwise to the ylide solution in THF (10 ml). To ensure complete transfer the flask containing the aldehyde was washed once more with THF (2 ml) and the contents added to the ylide solution. After 10 minutes TLC showed complete consumption of the starting material and water was added to quench the reaction. The reaction was poured into water and extracted 4 times with ethyl acetate. The combined organics were washed with water then brine, and dried with $\mathrm{MgSO}_{4}$. The solvent was removed under reduced pressure to produce the crude alkene which was purified by column chromatography on silica gel (EtOAc / hexanes as eluent) to yield alkene 15 (1.149 g, $2.010 \mathrm{mmol}, 73$ \%) as a white solid: m.p. $=123-125{ }^{\circ} \mathrm{C} ; \mathrm{R}_{\mathrm{f}}=0.68,33 \%$ EtOAc in hexane; ${ }^{1} \mathrm{H}-\mathrm{NMR}(600 \mathrm{MHz}$, $\mathrm{CDCl}_{3}$ ): $\delta=7.72$ (d, J = 8.4 Hz, 2H), 7.30 (d, J = 8.4 Hz, 2H), 6.53 (s, 1H), 5.01 (br.t, J = $6.0 \mathrm{~Hz}, 1 \mathrm{H}), 3.62$ (d, J = 6.0 Hz, 2H), 3.57 (s, 3H), 3.18-3.14 (m, 2H), 2.90-2.87 (m, 2H), 2.43 (s, 3H), 1.88-1.82 (m, 4H), 1.74 (s, 3H), 1.69 (s, 3H); ${ }^{13} \mathrm{C}$ NMR (100 MHz, $\left.\mathrm{CDCl}_{3}\right)$ $\delta=146.0,143.9$, 143.6, 140.7, 138.9, 132.3, 131.6, 129.2, 126.2, 125.7, 122.5, 120.2, 119.4, 118.4, 117.0, 100.7, 55.6, 26.5, 25.5, 25.0, 23.9, 22.9, 22.5, 21.5, 18.0; IR (thin film): 2940, 2860, 1620, 1582, 1496, 1418, 1368, 1313, 1242, 1213, 1177, 1141, 1094, 1031, 960, 906, 874, 830, 775, 666; HRMS calc'd for $\mathrm{C}_{26} \mathrm{H}_{28} \mathrm{~F}_{3} \mathrm{NO}_{6} \mathrm{~S}_{2}=571.1310$, found $=571.1306$.

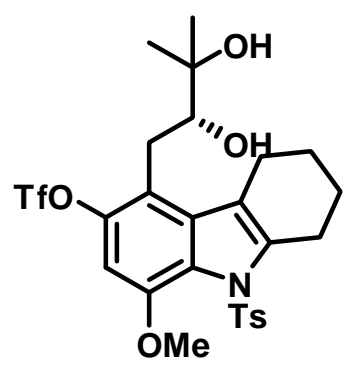

Intermediate B

$\mathrm{K}_{2} \mathrm{CO}_{3}$ (943 mg, $6.823 \mathrm{mmol}$ ), $\mathrm{K}_{3} \mathrm{Fe}(\mathrm{CN})_{6}$ ( $2.246 \mathrm{~g}, 6.821 \mathrm{mmol}$ ), $\mathrm{K}_{2} \mathrm{OsO}_{2}(\mathrm{OH})_{4}$ (32 mg, $0.0563 \mathrm{mmol}$ ), and (DHQD) ${ }_{2} \mathrm{PHAL}$ (267 $\mathrm{mg}, 0.228 \mathrm{mmol})$ were dissolved in $\mathrm{tBuOH}(12.5 \mathrm{ml})$ and $\mathrm{H}_{2} \mathrm{O}$ (12.5 ml). Methanesulfonamide (433 mg, $4.552 \mathrm{mmol}$ ) and alkene $15(1.300 \mathrm{~g}, 2.274 \mathrm{mmol})$ were then added and the reaction vigorously stirred for 44 hours after which TLC showed complete consumption of the starting material. $\mathrm{Na}_{2} \mathrm{SO}_{3}(1.433 \mathrm{~g}, 11.369$ mmol) was then added and the solution stirred for 1 hour after which the reaction was poured into water and extracted 3 times with ethyl acetate. The combined organics were washed with water then brine, and dried with $\mathrm{MgSO}_{4}$. The solvent was removed under reduced pressure to yield the crude diol as an off-white foam that was purified by column chromatography on silica gel (EtOAc / hexanes as eluent) to yield diol intermediate $\mathbf{B}(1.331 \mathrm{~g}, 2.198 \mathrm{mmol}$, $98 \%$ ) as a white solid: $\mathrm{R}_{\mathrm{f}}=0.25,33 \%$ EtOAc in hexanes; ${ }^{1} \mathrm{H}-\mathrm{NMR}\left(400 \mathrm{MHz}, \mathrm{CDCl}_{3}\right)$ : $\delta=7.75-7.72$ and 7.32-7.29 (m, AA'BB', 4H), 6.57 (s, 1H), 3.64 (br.d, $\mathrm{J}=11.2 \mathrm{~Hz}, 1 \mathrm{H}$ ), 3.58 (s, 3H), 3.22-3.06 (m, 5H), 2.82-2.73 (m, 1H), 2.43 (s, 3H), 2.16 (br.s, $1 \mathrm{H}), 1.94-$ 1.76 (m, 5H), 1.33 (s, 3H), 1.31 (s, 3H); ${ }^{13} \mathrm{C}$ NMR $\left(100 \mathrm{MHz}, \mathrm{CDCl}_{3}\right) \delta=146.4,144.8$, 143.7, 141.1, 138.9, 132.5, 129.2, 126.2, 125.7, 123.2, 120.0, 118.6, 116.8, 116.7, 113.7, 100.7, 78.0, 72.7, 55.6, 27.8, 26.5, 26.3, 24.8, 23.6, 22.8, 22.5, 21.5; IR (thin film): 3545, 3422, 2974, 2943, 2863, 1621, 1597, 1582, 1496, 1441, 1418, 1367, 1313, 1276, 1242, 1214, 1175, 1141, 1122, 1092, 1066, 1042, 1011, 980, 965, 935, 906, 861, 832, 815, 767, 
734, 669, 636; HRMS calc'd for $\mathrm{C}_{26} \mathrm{H}_{30} \mathrm{~F}_{3} \mathrm{NO}_{8} \mathrm{~S}_{2}=605.1365$, found $=605.1354 ;[\alpha]_{\mathrm{D}}=$ $+11.9^{\circ}(c=0.536, \mathrm{MeOH})$.

The enantiomeric excess was determined to be $45 \%$ by chiral shift reagent (Europium tris[3-(heptafluoro-propylhydroxymethylene)-(+)-camphorate]). Peak monitored is at $6.57 \mathrm{ppm}(\mathrm{s}, 1 \mathrm{H})$. Upon addition of the chiral shift reagent the (-) enantiomer is shifted downfield with respect to the $(+)$ enantiomer.

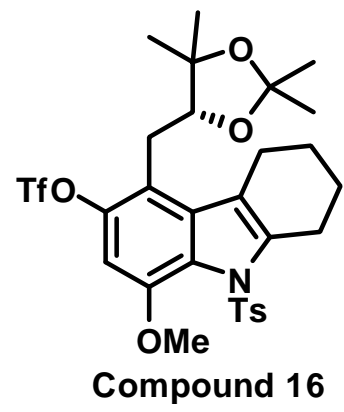

Diol intermediate $\mathbf{B}$ (1.793 g, $2.960 \mathrm{mmol})$ and paratoluenesulfonic acid (169 $\mathrm{mg}, 0.888 \mathrm{mmol}$ ) were dissolved in DMF (20 ml) and cooled to $0{ }^{\circ} \mathrm{C}$. 2-methoxypropene $(1.42 \mathrm{ml}, 14.828 \mathrm{mmol})$ was then added and the solution allowed to warm to room temperature over 12 hours, after which TLC showed complete consumption of the starting material. The reaction was poured into water and extracted 4 times with ethyl acetate. The combined organics were washed with water then brine, and dried with $\mathrm{MgSO}_{4}$. The solvent was removed under reduced pressure to give a crude mixture that was purified by column chromatography on silica gel (ethyl acetate / hexanes as eluent) to yield acetonide 16 (1.866 g, $2.900 \mathrm{~mol}, 98 \%$ ) as a white solid: $\mathrm{R}_{\mathrm{f}}=0.65$, $33 \%$ EtOAc in hexanes; ${ }^{1} \mathrm{H}-\mathrm{NMR}\left(600 \mathrm{MHz}, \mathrm{CDCl}_{3}\right): \delta=7.75(\mathrm{~d}, \mathrm{~J}=8.1 \mathrm{~Hz}, 2 \mathrm{H}), 7.31$ (d, J = 8.1 Hz, 2H), 6.57 (s, 1H), 3.89 (d, J = 9 Hz, 1H), 3.59 (s, 3H), 3.30-3.22 (m, 2H), 3.17 (br.s, 2H), 2.93 (d, J = 14.4 Hz, 1H), 2.77-2.71 (m, 1H), 2.43 (s, 3H), 1.93-1.78 (m, 4H), 1.40 (s, 3H), 1.31 (s, 3H), 1.25 (s, 3H), 1.20 (s, 3H); ${ }^{13} \mathrm{C}$ NMR (100 MHz, $\left.\mathrm{CDCl}_{3}\right) \delta=146.4$, 144.3, 143.7, 141.0, 139.1, 132.4, 129.3, 126.3, 125.8, 120.1, 118.7, 116.9, 116.6, 107.0, 100.7, 83.3, 80.2, 55.6, 28.2, 26.7, 26.6, 25.9, 25.8, 24.7, 23.1, 22.9, 22.5, 21.6; IR (thin film): 2981, 2939, 2863, 1620, 1582, 1496, 1418, 1370, 1338, 1314, 1270, 1243, 1215, 1188, 1176, 1141, 1119, 1104, 1093, 1051, 1017, 1000, 980, 965, 932, 889, 874, 841, 814, 776, 766, 734, 704, 670, 609, 574 ; HRMS calc'd for $\mathrm{C}_{29} \mathrm{H}_{34} \mathrm{~F}_{3} \mathrm{NO}_{8} \mathrm{~S}_{2}=645.1678$, found $=645.1671$.

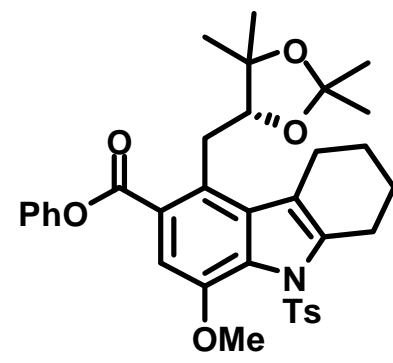

Intermediate C

Acetonide 16 (1.238 g, $1.917 \mathrm{mmol})$, phenol (1.804 g, 19.169 $\mathrm{mmol})$, and $\mathrm{Pd}\left(\mathrm{PPh}_{3}\right)_{4}(665 \mathrm{mg}, 0.575 \mathrm{mmol})$ were dissolved in $\mathrm{NEt}_{3}(3 \mathrm{ml})$ and dioxane $(17 \mathrm{ml})$. CO was bubbled through the solution for 20 minutes and while maintaining an atmosphere of $\mathrm{CO}$ the reaction mixture was heated to $95^{\circ} \mathrm{C}$ for 4 days after which TLC showed that some starting material still remained. Regardless, the reaction was poured into water and extracted 4 times with ethyl acetate. The combined organics were washed with water then brine, and dried with $\mathrm{MgSO}_{4}$. The solvent was removed under reduced pressure to give a crude mixture that was purified by column chromatography on silica gel (ethyl acetate / hexanes as eluent) to yield ester intermediate C (703 mg, $1.138 \mathrm{mmol}, 59 \%$ ) as a white solid along with recovered acetonide 16 (471 mg, $0.729 \mathrm{mmol}$ ). The recovered acetonide was resubjected to the reaction conditions. Acetonide 16 (471 mg, $0.729 \mathrm{mmol}$ ), phenol (686 mg, $7.289 \mathrm{mmol}$ ), 
and $\mathrm{Pd}\left(\mathrm{PPh}_{3}\right)_{4}$ (253 mg, $\left.0.219 \mathrm{mmol}\right)$ were dissolved in $\mathrm{NEt}_{3}(1.5 \mathrm{ml})$ and dioxane (10 $\mathrm{ml})$. CO was bubbled through the solution for 20 minutes and while maintaining an atmosphere of CO the reaction mixture was heated to $95^{\circ} \mathrm{C}$ for 4 days after which TLC showed that some starting material still remained. Regardless, the reaction was poured into water and extracted 4 times with ethyl acetate. The combined organics were washed with water then brine, and dried with $\mathrm{MgSO}_{4}$. The solvent was removed under reduced pressure to give a crude mixture that was purified by column chromatography on silica gel (ethyl acetate / hexanes as eluent) to yield ester intermediate $\mathbf{C}$ (140 mg, $0.227 \mathrm{mmol}$, $31 \%$ ) as a white solid along with recovered starting material acetonide 16 (318 mg, $0.675 \mathrm{mmol})$. Therefore, two cycles yielded ester intermediate $\mathbf{C}$ (843 mg, 1.364, 71 \% over 2 cycles, or $96 \%$ BRSM) along with unreacted starting material (318 mg, 0.675 mmol): $\mathrm{R}_{\mathrm{f}}=0.57,33 \%$ EtOAc in hexanes; ${ }^{1} \mathrm{H}-\mathrm{NMR}\left(600 \mathrm{MHz}, \mathrm{CDCl}_{3}\right): \delta=7.77(\mathrm{~d}, \mathrm{~J}=$ $8.7 \mathrm{~Hz}, 2 \mathrm{H}), 7.45$ (s, 1H), 7.42 (t, J = 7.8 Hz, 2H), 7.31 (d, J = 8.7 Hz, 2H), 7.26 (t, J = $7.8 \mathrm{~Hz}, 1 \mathrm{H}$ ), 7.19 (d, J = 7.8 Hz, 2H), 3.94 (dd, J = 9.6, 3.0 Hz, 1H), 3.65 (s, 3H), 3.603.53 (m, 2H), 3.49-3.44 (m, 1H), 3.19 (br.s, 2H), 2.82-2.76 (m, 1H), 2.43 (s, 3H), 1.951.78 (m, 4H), 1.40 (s, 3H), 1.29 (s, 3H), 1.22 (s, 3H), 1.19 (s, 3H); ${ }^{13} \mathrm{C}$ NMR (100 MHz, $\left.\mathrm{CDCl}_{3}\right) \delta=166.2$, 151.0, 145.5, 143.5, 140.0, 139.3, 133.0, 129.6, 129.4, 129.2, 128.9, 126.2, 125.7, 124.9, 121.8, 119.2, 110.0, 106.6, 84.8, 80.4, 55.5, 28.3, 27.7, 26.7, 26.1, 25.6, 23.4, 23.0, 22.7, 21.6; IR (thin film): 3098, 3063, 3043, 2979, 2935, 2859, 1734, 1594, 1494, 1479, 1457, 1403, 1369, 1337, 1315, 1271, 1216, 1188, 1176, 1159, 1112 , 1093, 1031, 1016, 999, 965, 921, 839, 813, 772, 738, 670, 667; HRMS calc'd for $\mathrm{C}_{39} \mathrm{H}_{39} \mathrm{NO}_{7} \mathrm{~S}=617.2447$, found $=617.2443$.

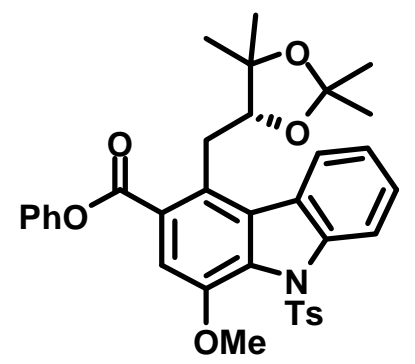

Compound 17

Ester intermediate C (201 mg, $0.325 \mathrm{mmol})$ and 2,3-dichloro5,6-dicyano-1,4-benzoquinone (221 $\mathrm{mg}, 0.974 \mathrm{mmol}$ ) were dissolved in benzene $(5 \mathrm{ml})$ and added to a $2-5 \mathrm{ml}$ microwave vial. The head space was purged with Ar and the vial capped and heated to $100{ }^{\circ} \mathrm{C}$ for 2 hours, after which TLC showed complete consumption of the starting material. The reaction was transferred to a round bottom flask and the solvent was removed under reduced pressure to give a crude mixture that was purified by column chromatography on silica gel (ethyl acetate / hexanes as eluent) to yield carbazole 17 (187 $\mathrm{mg}, 0.305 \mathrm{mmol}, 94 \%)$ as a very pale yellow solid: $\mathrm{R}_{\mathrm{f}}=0.51,33 \%$ EtOAc in hexanes; ${ }^{1} \mathrm{H}-\mathrm{NMR}\left(600 \mathrm{MHz}, \mathrm{CDCl}_{3}\right): \delta=8.43(\mathrm{t}, \mathrm{J}=8.4 \mathrm{~Hz}$, 2H), 7.84-7.82 and 7.25-7.22 (m, AA'BB', 4H), 7.67 (s, 1H), 7.55 (dt, J = 8.4, 1.2 Hz, 1H), 7.47-7.43 (m, 2H), 7.41 (dt, J = 8.4, $1.2 \mathrm{~Hz}, 1 \mathrm{H}), 7.31-7.28(\mathrm{~m}, 3 \mathrm{H}), 4.13$ (X of ABX system, $\mathrm{J}=10.3,3.3 \mathrm{~Hz}, 1 \mathrm{H}$ ), 3.94 (B of ABX system, $\mathrm{J}=14.3,10.3 \mathrm{~Hz}, 1 \mathrm{H}$ ), 3.78 (s, 3H), 3.75 (A of ABX system, J = 14.3, $3.3 \mathrm{~Hz}, 1 \mathrm{H}), 2.43$ (s, 3H), 1.39 (s, 3H), 1.35 (s, 3H), 1.33 (s, 3H), 1.15 (s, 3H); ${ }^{13} \mathrm{C}$ NMR (150 MHz, $\left.\mathrm{CDCl}_{3}\right) \delta=165.9,150.9,146.4$, 143.9, 141.4, 138.5, 131.9, 130.3, 129.5, 129.3, 128.9, 127.2, 126.7, 126.3, 125.9, 123.8, 123.5, 121.7, 116.9, 113.1, 106.8, 83.8, 80.5, 55.7, 28.4, 26.7. 26.1, 23.5, 21.6; IR (thin film): 3047, 2980, 2935, 2872, 1735, 1595, 1496, 1457, 1369, 1338, 1280, 1219, 1189, 1154, 1114, 1093, 1019, 1000, 957, 921, 811, 771, 742, 690, 668, 657; HRMS calc'd for $\mathrm{C}_{35} \mathrm{H}_{35} \mathrm{NO}_{7} \mathrm{~S}=613.2134$, found $=613.2126$. 


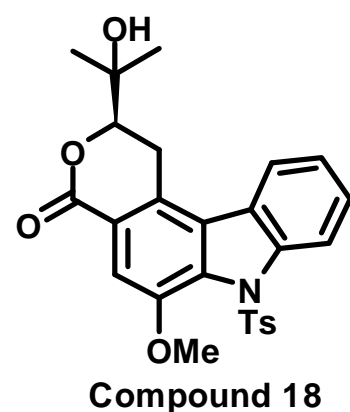

Carbazole 17 (123 mg, $0.200 \mathrm{mmol}$ ) and paratoluenesulfonic acid (40 mg g, $0.210 \mathrm{mmol}$ ) were dissolved in THF $(8 \mathrm{ml})$ and ethylene glycol (2 ml) and the mixture was brought to reflux for 7 hours, after which TLC showed complete consumption of the starting material. The reaction was poured into water and extracted 4 times with ethyl acetate. The combined organics were washed with water then brine, and dried with $\mathrm{MgSO}_{4}$. The solvent was removed under reduced pressure to give a crude mixture that was purified by column chromatography on silica gel (ethyl acetate / hexanes as eluent) to yield alcohol 18 (95 mg, $0.198 \mathrm{mmol}, 99 \%$ ) as a white solid: $\mathrm{R}_{\mathrm{f}}=0.24,50 \%$ EtOAc in hexanes; ${ }^{1} \mathrm{H}-\mathrm{NMR}\left(600 \mathrm{MHz}, \mathrm{CDCl}_{3}\right): \delta=8.47(\mathrm{~d}, \mathrm{~J}=8.4 \mathrm{~Hz}, 1 \mathrm{H}), 8.02(\mathrm{~d}, \mathrm{~J}=$ $8.4 \mathrm{~Hz}, 1 \mathrm{H}), 7.81(\mathrm{~d}, \mathrm{~J}=8.4 \mathrm{~Hz}, 2 \mathrm{H}), 7.62(\mathrm{~s}, 1 \mathrm{H}), 7.58(\mathrm{t}, \mathrm{J}=8.4 \mathrm{~Hz}, 1 \mathrm{H}), 7.46(\mathrm{t}, \mathrm{J}=$ $8.4 \mathrm{~Hz}, 1 \mathrm{H}), 7.31$ (d, J = 8.4 Hz, 2H), 4.41 (X of ABX system, J = 12.6, $3.6 \mathrm{~Hz}, 1 \mathrm{H}$ ), 3.74 (s, 3H), 3.60 (B of ABX system, $\mathrm{J}=16.2,3.6 \mathrm{~Hz}, 1 \mathrm{H}$ ), 3.41 (A of ABX system, $\mathrm{J}=$ 16.2, $12.6 \mathrm{~Hz}, 1 \mathrm{H}), 2.43$ (s, 3H), 2.24 (s, 1H), 1.48 (s, 3H), 1.45 (s, 3H); ${ }^{13} \mathrm{C}$ NMR (150 $\left.\mathrm{MHz}, \mathrm{CDCl}_{3}\right) \delta=165.3,147.2,144.2,141.3,138.3,132.3,129.4,127.6,127.2,126.3$, 125.63, 125.56, 124.1, 121.9, 120.9, 117.1, 110.8, 83.9, 71.3, 55.7, 25.8, 25.2, 25.1, 21.6; IR (thin film): 3447, 3076, 2975, 2934, 2853, 1718, 1601, 1499, 1451, 1362, 1321, 1280, 1213, 1176, 1118, 1092,1067, 1023, 962, 914, 813, 777, 732, 684, 656; HRMS calc'd for $\mathrm{C}_{26} \mathrm{H}_{25} \mathrm{NO}_{6} \mathrm{~S}=479.1403$, found $=479.1377$.

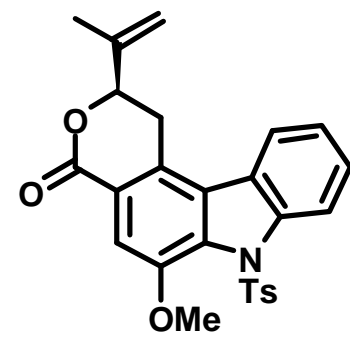

Intermediate D

Alcohol 18 (68 mg, $0.142 \mathrm{mmol}$ ) and Martin’s sulfurane (143 mg, $0.213 \mathrm{mmol}$ ) were added to a schlenk tube and the vessel was evacuated and filled with $\mathrm{N}_{2}$. DCM (5 ml) was then added and the reaction allowed to stir for 20 minutes, after which TLC showed complete consumption of the starting material. The reaction mixture was then transferred to a round bottom flask and the solvent was removed under reduced pressure to give a crude mixture that was purified by column chromatography on silica gel (ethyl acetate / hexanes as eluent) to yield alkene intermediate D (51 mg, $0.111 \mathrm{mmol}, 77 \%$ ) as a white solid: $\mathrm{R}_{\mathrm{f}}=0.63$, $50 \%$ EtOAc in hexanes; ${ }^{1} \mathrm{H}$ NMR (600 MHz, $\left.\mathrm{CDCl}_{3}\right): \delta=8.47(\mathrm{~d}, \mathrm{~J}=8.1 \mathrm{~Hz}, 1 \mathrm{H}), 8.02(\mathrm{~d}, \mathrm{~J}=8.1 \mathrm{~Hz}, 1 \mathrm{H}), 7.81(\mathrm{~d}, \mathrm{~J}$ $=8.1 \mathrm{~Hz}, 2 \mathrm{H}), 7.65(\mathrm{~s}, 1 \mathrm{H}), 7.56(\mathrm{t}, \mathrm{J}=8.1 \mathrm{~Hz}, 1 \mathrm{H}), 7.45(\mathrm{t}, \mathrm{J}=8.1 \mathrm{~Hz}, 1 \mathrm{H}), 7.31(\mathrm{~d}, \mathrm{~J}=$ $8.1 \mathrm{~Hz}, 2 \mathrm{H}$ ), 5.22 (s, 1H), 5.11 (s, 1H), 5.04 (X of ABX system, J = 11.5, $3.5 \mathrm{~Hz}, 1 \mathrm{H}$ ), 3.75 (s, 3H), 3.59 (B of ABX system, $\mathrm{J}=16.2,3.5 \mathrm{~Hz}, 1 \mathrm{H}$ ), 3.47 (A of ABX system, $\mathrm{J}=$ 16.2, $11.5 \mathrm{~Hz}, 1 \mathrm{H}), 2.43$ (s, 3H), 1.97 (s, 3H); ${ }^{13} \mathrm{C} \mathrm{NMR}\left(100 \mathrm{MHz}, \mathrm{CDCl}_{3}\right) \delta=165.3$, 147.3, 144.2, 141.8, 141.5, 138.4, 132.3, 129.4, 127.6, 126.9, 126.4, 125.7, 125.5, 124.1, 121.8, 121.3, 117.2, 114.4, 111.1, 80.8, 55.7, 29.5, 21.6, 18.3; IR (thin film): 3061, 2974, 2922, 2850, 1718, 1599, 1499, 1451, 1357, 1321, 1279, 1222, 1175, 1155, 1117, 1091, 1066, 1043, 1023, 1003, 961, 930, 872, 831, 812, 778, 747, 704, 681, 656; HRMS calc'd for $\mathrm{C}_{26} \mathrm{H}_{23} \mathrm{NO}_{5} \mathrm{~S}=461.1297$, found $=461.1298$. 


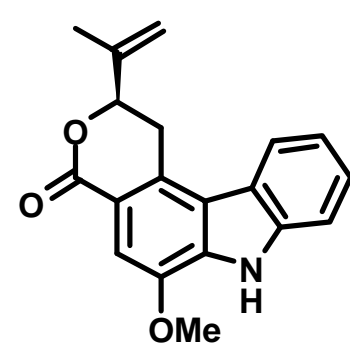

Clausamine B

Alkene intermediate D (34 mg, $0.0737 \mathrm{mmol}$ ) was dissolved in THF ( $5 \mathrm{ml})$ and added to a $2-5 \mathrm{ml}$ microwave vial. TBAF $(0.15 \mathrm{ml}$ of $1.0 \mathrm{M}$ solution in THF, $0.150 \mathrm{mmol}$ ) was then added dropwise. The head space was purged with $\mathrm{Ar}$ and the vial capped and heated to $60{ }^{\circ} \mathrm{C}$ for 20 minutes in the microwave, after which TLC showed complete consumption of the starting material. The reaction was poured into saturated $\mathrm{NH}_{4} \mathrm{Cl}$ solution and extracted 3 times with ethyl acetate. The combined organics were washed with water then brine, and dried with $\mathrm{MgSO}_{4}$. The solvent was removed under reduced pressure to give a crude mixture that was purified by column chromatography on silica gel (ethyl acetate / hexanes as eluent) to yield Clausamine B as a white solid along with a minor impurity. The solid was resubjected to column chromatography (DCM as eluent) to afford pure Clausamine B (19 mg, $0.0618 \mathrm{mmol}, 84$ $\%)$ as a white solid. The spectroscopic data for synthetic Clausamine B is in agreement with literature ${ }^{1}$, with the exception of the optical rotation: $\mathrm{R}_{\mathrm{f}}=0.66,50 \%$ EtOAc in hexanes; ${ }^{1} \mathrm{H}-\mathrm{NMR}\left(600 \mathrm{MHz}, \mathrm{CDCl}_{3}\right): \delta=8.67$ (br.s, $\left.1 \mathrm{H}\right), 8.07$ (d, J = 7.8 Hz, $\left.1 \mathrm{H}\right), 7.64$ (s, 1H) 7.54 (d, J = 7.8 Hz, 1H), 7.48 (dt, J = 7.8, 1.2 Hz, 1H), 7.30 (dt, J = 7.8, $1.8 \mathrm{~Hz}$, $1 \mathrm{H}$ ), 5.24 (s, 1H), 5.10 (s, 1H), 5.08 (X of ABX system, J = 11.7, $3.9 \mathrm{~Hz}, 1 \mathrm{H}$ ), 4.04 (s, $3 \mathrm{H}$ ), 3.62 (B of ABX system, $\mathrm{J}=16.2,3.9 \mathrm{~Hz}, 1 \mathrm{H}$ ), 3.48 (A of ABX system, $\mathrm{J}=16.2$, $11.7 \mathrm{~Hz}, 1 \mathrm{H}), 1.99$ (s, 3H); ${ }^{13} \mathrm{C}$ NMR (150 MHz, $\left.\mathrm{CDCl}_{3}\right) \delta=166.6,144.5,142.3,139.5$, 133.5, 128.7, 126.1, 123.3, 121.8, 120.5, 120.2, 116.2, 114.0, 111.6, 106.4, 80.8, 55.9, 29.5, 18.4; IR (thin film): 3311, 3076, 2920, 2837, 1690, 1587, 1507, 1457, 1357, 1310, 1253, 1228, 1162, 1148, 1115, 1083, 1064, 1042, 1004, 900, 849, 733; HRMS calc'd for $\mathrm{C}_{19} \mathrm{H}_{17} \mathrm{NO}_{3}=307.1208$, found $=307.1211 ;[\alpha]_{\mathrm{D}}=+62.8^{\circ}\left(c=0.083, \mathrm{CHCl}_{3}\right),[\alpha]_{\mathrm{D}}=$ $+63.0^{\circ}\left(c=0.276, \mathrm{CHCl}_{3}\right)$, literature $[\alpha]_{\mathrm{D}}=0^{\circ}\left(c=0.082, \mathrm{CHCl}_{3}\right){ }^{1}$

The enantiomeric excess was determined to be $46 \%$ by chiral HPLC, Chiralcel OD-H, 250 x $4.6 \mathrm{~mm}^{2}$, Diacel Chemical Industries; 96:3:1 Hexanes / MeOH / EtOH at 1.5 $\mathrm{mL} / \mathrm{min}$; $220 \mathrm{~nm}$; The retention time for the enantiomers were $\mathrm{r}_{1}(-)=18.75 \mathrm{~min}, \mathrm{r}_{1}(+)=$ $21.08 \mathrm{~min}$.

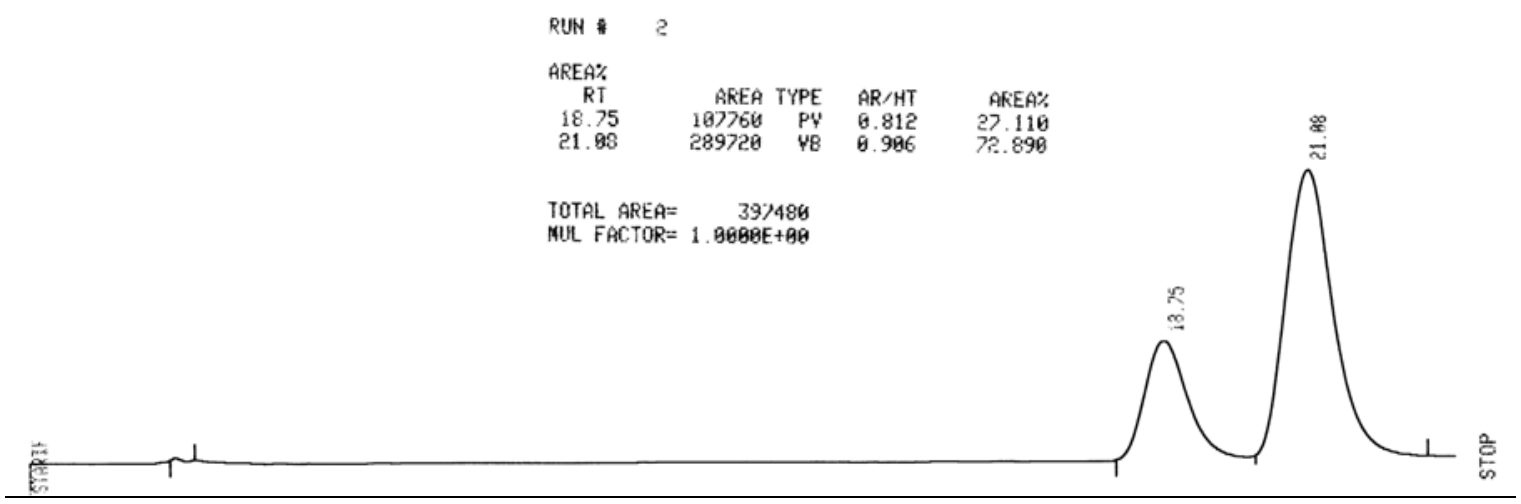




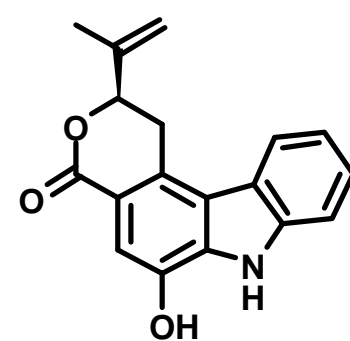

Clausamine A

Clausamine B (29 mg, $0.0944 \mathrm{mmol}$ ) was dissolved in DCM (5 $\mathrm{ml}) . \mathrm{BBr}_{3}(0.50 \mathrm{ml}$ of $1.0 \mathrm{M}$ solution in DCM, $0.500 \mathrm{mmol})$ was added dropwise and the solution allowed to stir for 2 hours at which point a second addition of $\mathrm{BBr}_{3}(0.50 \mathrm{ml}$ of $1.0 \mathrm{M}$ solution in DCM, $0.500 \mathrm{mmol}$ ) was added. The solution was stirred for an additional hour, after which TLC showed complete consumption of the starting material. Saturated $\mathrm{NaHCO}_{3}$ solution $(10 \mathrm{ml})$ and EtOAc $(10 \mathrm{ml})$ was added to quench the excess $\mathrm{BBr}_{3}$ (cautiously at first) and the mixture was stirred for 4.5 hours. The reaction was poured into $5 \% \mathrm{HCl}$ solution and extracted 3 times with ethyl acetate. The combined organics were washed with water then brine, and dried with $\mathrm{MgSO}_{4}$. The solvent was removed under reduced pressure to give a crude mixture that was purified by column chromatography on silica gel (ethyl acetate / hexanes as eluent) followed by a second column (acetone / hexanes as eluent) to yield Clausamine A (21 mg, $0.0716 \mathrm{mmol}, 75 \%$ ) as a pale yellow solid. The spectroscopic data for synthetic Clausamine $\mathrm{A}$ is in agreement with literature ${ }^{1}$, with the exception of the optical rotation: $R_{f}=0.59,50 \%$ acetone in hexanes; ${ }^{1} \mathrm{H}-\mathrm{NMR}$ (400 MHz, acetone- $\mathrm{d}_{6}$ ): $\delta=10.82$ (br.s, $1 \mathrm{H}$ ), 9.17 (br.s, $1 \mathrm{H}$ ), 8.18 (d, J $=8.2 \mathrm{~Hz}, 1 \mathrm{H}$ ), 7.66 (ddd, $\mathrm{J}=8.0,1.2,0.8 \mathrm{~Hz}, 1 \mathrm{H}$ ), 7.57 (s, $1 \mathrm{H}$ ), 7.45 (ddd, $\mathrm{J}=8.0,7.2$, $1.2 \mathrm{~Hz}, 1 \mathrm{H}$ ), 7.25 (ddd, 8.2, 7.2, $0.8 \mathrm{~Hz}, 1 \mathrm{H}$ ), 5.27-5.25 (m, 1H), 5.12 (X of ABX system, $\mathrm{J}=11.7,3.5,1 \mathrm{H}$ ), 5.08-5.06 (m, 1H), 3.70 (B of ABX system, $\mathrm{J}=16.4,3.5,1 \mathrm{H}), 3.51$ (A of ABX system, $\mathrm{J}=16.4,11.4 \mathrm{~Hz}, 1 \mathrm{H}) 1.97$ (s, 3H); ${ }^{13} \mathrm{C}$ NMR $(100 \mathrm{MHz}$, Acetone$\left.\mathrm{d}_{6}\right) \delta=166.1,144.2,142.8,141.4,134.4,128.6,126.6,124.3,122.9,121.5,120.7,117.0$, 113.6, 112.6, 110.9, 81.2, 30.2, 18.6; IR (thin film): 3320, 3101, 3056, 2976, 2922, 1696, 1670, 1628, 1589, 1508, 1457, 1367, 1313, 1262, 1231, 1142, 1113, 1084, 1064, 902, 856, 779, 730; HRMS calc'd for $\mathrm{C}_{18} \mathrm{H}_{15} \mathrm{NO}_{3}=293.1052$, found $=293.1054 ;[\alpha]_{\mathrm{D}}=$ $+33.2^{\circ}\left(c=0.063, \mathrm{CHCl}_{3}\right),[\alpha]_{\mathrm{D}}=+34.6^{\circ}\left(c=0.211, \mathrm{CHCl}_{3}\right)$, literature $[\alpha]_{\mathrm{D}}=0^{\circ}(c=$ $\left.0.072, \mathrm{CHCl}_{3}\right){ }^{1}$

The enantiomeric excess was determined to be $35 \%$ by chiral HPLC, Chiralcel OD-H, 250 x $4.6 \mathrm{~mm}^{2}$, Diacel Chemical Industries; 96:3:1 Hexanes / MeOH / EtOH at 1.5 $\mathrm{mL} / \mathrm{min}$; $220 \mathrm{~nm}$; The retention time for the enantiomers were $\mathrm{r}_{\mathrm{l}}(-)=17.88 \mathrm{~min}, \mathrm{r}_{\mathrm{l}}(+)=$ $19.69 \mathrm{~min}$.

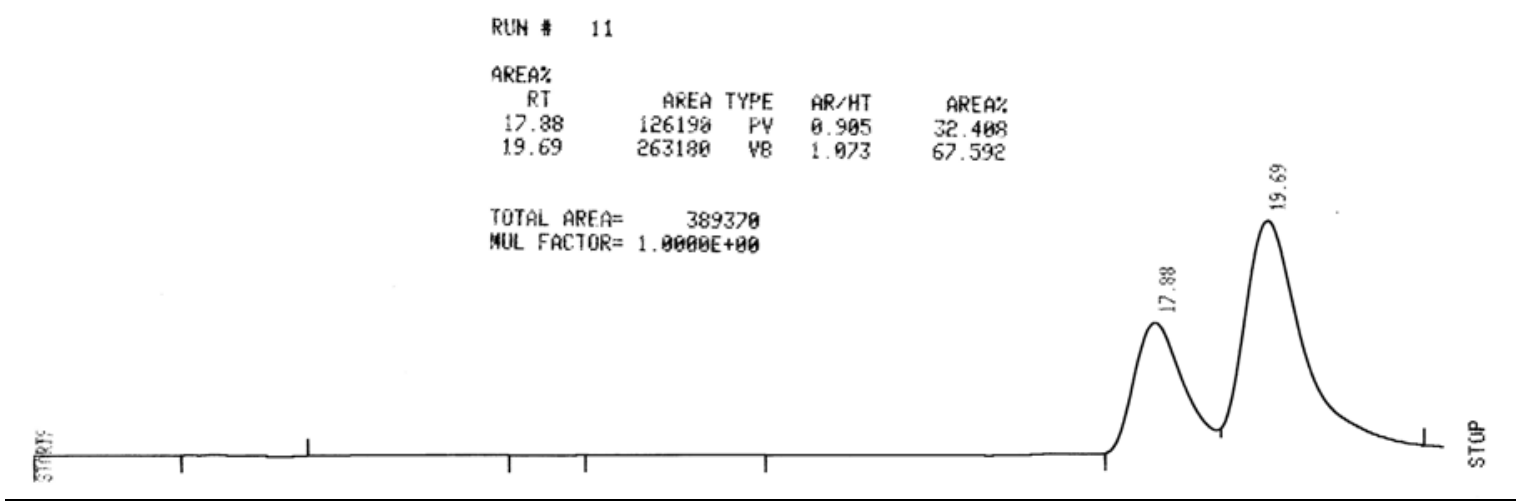




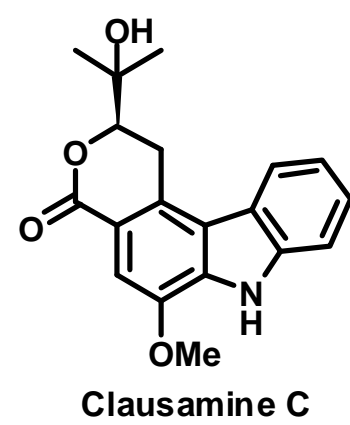
column chromatography on silica gel (ethyl acetate / hexanes as eluent) to yield Clausamine C (42 mg, $0.129 \mathrm{mmol}, 82 \%$ ) as a white solid The spectroscopic data for synthetic Clausamine $\mathrm{C}$ is in agreement with literature ${ }^{1}$, with the exception of the optical rotation: $\mathrm{R}_{\mathrm{f}}=0.53,80 \%$ EtOAc in hexanes; ${ }^{1} \mathrm{H}-\mathrm{NMR}\left(400 \mathrm{MHz}, \mathrm{CDCl}_{3}\right): \delta=8.74$ (br.s, 1H), 8.05 (d, J = 8.0 Hz, 1H), 7.60 (s, 1H), 7.54 (d, J = 8.0 Hz, 1H), 7.48 (t, J = 8.0 Hz, $1 \mathrm{H}), 7.30$ (t, $\mathrm{J}=8.0 \mathrm{~Hz}, 1 \mathrm{H}), 4.44$ (X of ABX system, $\mathrm{J}=13.5,3.3 \mathrm{~Hz}, 1 \mathrm{H}), 4.03$ (s, $3 \mathrm{H}$ ), 3.62 (B of ABX system, $\mathrm{J}=16.2,3.3 \mathrm{~Hz}, 1 \mathrm{H}$ ), 3.41 (A of ABX system, $\mathrm{J}=16.2$, $13.5 \mathrm{~Hz}, 1 \mathrm{H}), 2.41$ (br.s, $1 \mathrm{H}), 1.49$ (s, 3H), 1.46 (s, 3H); ${ }^{13} \mathrm{C} \mathrm{NMR}\left(100 \mathrm{MHz}, \mathrm{CDCl}_{3}\right) \delta=$ 166.5, 144.6, 139.5, 133.6, 128.9, 126.2, 123.4, 121.9, 120.6, 120.4, 115.9, 111.6, 106.4, 84.0, 71.4, 55.9, 26.0, 25.4, 24.9; IR (thin film): 3352, 3091, 3059, 2976, 2936, 2837, 1685, 1587, 1507, 1457, 1430. 1358, 1310, 1253, 1226, 1162, 1148, 1116, 1094, 1064, 1037, 1013, 909, 852, 777, 733; HRMS calc'd for $\mathrm{C}_{19} \mathrm{H}_{19} \mathrm{NO}_{4}=325.1314$, found = 325.1319; $[\alpha]_{\mathrm{D}}=+50.0^{\circ}\left(c=0.036, \mathrm{CHCl}_{3}\right),[\alpha]_{\mathrm{D}}=+53.8^{\circ}\left(c=0.950, \mathrm{CHCl}_{3}\right)$, literature $[\alpha]_{\mathrm{D}}=0^{\circ}\left(c=0.037, \mathrm{CHCl}_{3}\right){ }^{1}$

The enantiomeric excess was determined to be $47 \%$ by chiral HPLC, Chiralcel OD-H, 250 x $4.6 \mathrm{~mm}^{2}$, Diacel Chemical Industries; 94:4.5:1.5 Hexanes / $\mathrm{MeOH} / \mathrm{EtOH}$ at 1.5 $\mathrm{mL} / \mathrm{min} ; 220 \mathrm{~nm}$; The retention time for the enantiomers were $r_{1}(-)=16.73 \mathrm{~min}, \mathrm{r}_{\mathrm{l}}(+)=$ $19.23 \mathrm{~min}$.

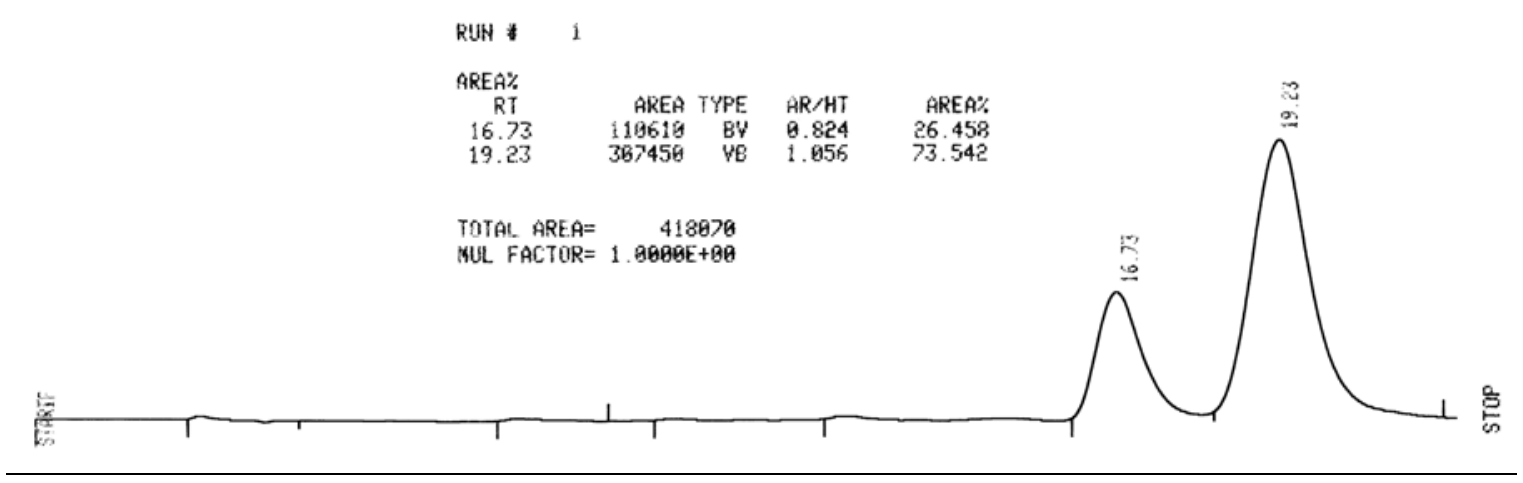




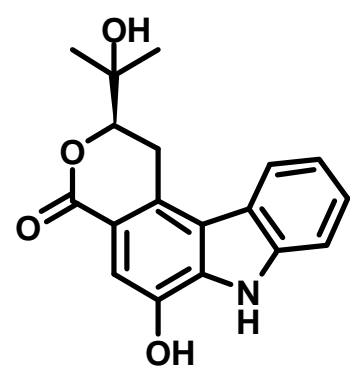

Clausevatine D

Clausamine C (26 mg, $0.0799 \mathrm{mmol}$ ) was dissolved in DCM (5 $\mathrm{ml}) . \mathrm{BBr}_{3}(0.50 \mathrm{ml}$ of $1.0 \mathrm{M}$ solution in DCM, $0.500 \mathrm{mmol})$ was added dropwise and the solution allowed to stir for 2 hours at which point a second addition of $\mathrm{BBr}_{3}(0.50 \mathrm{ml}$ of $1.0 \mathrm{M}$ solution in DCM, $0.500 \mathrm{mmol}$ ) was added. The solution was stirred for an additional 2.5 hours, after which TLC showed complete consumption of the starting material. Saturated $\mathrm{NaHCO}_{3}$ solution $(10 \mathrm{ml})$ and EtOAc $(10 \mathrm{ml})$ was added to quench the excess $\mathrm{BBr}_{3}$ (cautiously at first) and the mixture was stirred for 3 hours. The reaction was poured into $5 \% \mathrm{HCl}$ solution and extracted 3 times with ethyl acetate. The combined organics were washed with water then brine, and dried with $\mathrm{MgSO}_{4}$. The solvent was removed under reduced pressure to give a crude mixture that was purified by column chromatography on silica gel (acetone / hexanes as eluent) to yield Clausevatine D (18 mg, $0.0578 \mathrm{mmol}, 72 \%$ ) as a colourless oil. The spectroscopic data for synthetic Clausevatine $\mathrm{D}$ is in agreement with literature ${ }^{2}$, with the exception of the optical rotation: $\mathrm{R}_{\mathrm{f}}=0.38,50 \%$ acetone in hexanes; ${ }^{1} \mathrm{H}-\mathrm{NMR}(600 \mathrm{MHz}$, Acetone$\mathrm{d}_{6}$ ): $\delta=10.83$ (br.s, $1 \mathrm{H}$ ), 9.15 (br.s, $1 \mathrm{H}$ ), 8.21 (d, J = 7.8 Hz, 1H), 7.67 (d, J = 7.8 Hz, $1 \mathrm{H}), 7.56(\mathrm{~s}, 1 \mathrm{H}), 7.46(\mathrm{t}, \mathrm{J}=7.8 \mathrm{~Hz}, 1 \mathrm{H}), 7.27(\mathrm{t}, \mathrm{J}=7.8 \mathrm{~Hz}, 1 \mathrm{H}), 4.45$ (dd, $\mathrm{J}=12.6,3.3$ Hz, 1H), 3.99 (br.s, 1H), 3.78 (dd, J = 16.5, $3.3 \mathrm{~Hz}, 1 \mathrm{H}$ ), 3.43 (dd, J = 16.5, $12.6 \mathrm{~Hz}, 1 \mathrm{H}$ ), 1.43 (s, 6H); ${ }^{13} \mathrm{C}$ NMR (100 MHz, Acetone- $\left.\mathrm{d}_{6}\right) \delta=166.3$, 142.7, 141.4, 134.4, 129.1, 126.6, 124.4, 122.9, 121.7, 120.7, 116.9, 112.7, 110.8, 84.8, 71.3, 26.8, 26.0, 25.4; IR (thin film): 3323, 2982, 2938, 1692, 1588, 1509, 1455, 1423, 1361, 1313, 1275, 1228, 1210, 1158, 1142, 1114, 1094, 1062, 1018, 998, 956, 918, 856, 779, 750, 735; HRMS calc'd for $\mathrm{C}_{18} \mathrm{H}_{17} \mathrm{NO}_{4}=311.1158$, found $=311.1149 ;[\alpha]_{\mathrm{D}}=+55.0^{\circ}(c=0.433, \mathrm{MeOH})$, $[\alpha]_{\mathrm{D}}=+50.7^{\circ}(c=1.380, \mathrm{MeOH})$, literature $[\alpha]_{\mathrm{D}}=-5.7^{\circ}(c=0.932, \mathrm{MeOH}) .^{2}$

The enantiomeric excess was determined to be $49 \%$ by chiral HPLC, Chiralcel OD-H, 250 x $4.6 \mathrm{~mm}^{2}$, Diacel Chemical Industries; 90:7.5:2.5 Hexanes / $\mathrm{MeOH} / \mathrm{EtOH}$ at 1.5 $\mathrm{mL} / \mathrm{min} ; 220 \mathrm{~nm}$; The retention time for the enantiomers were $\mathrm{r}_{\mathrm{l}}(-)=12.19$ min, $\mathrm{r}_{\mathrm{l}}(+)=$ $14.44 \mathrm{~min}$.

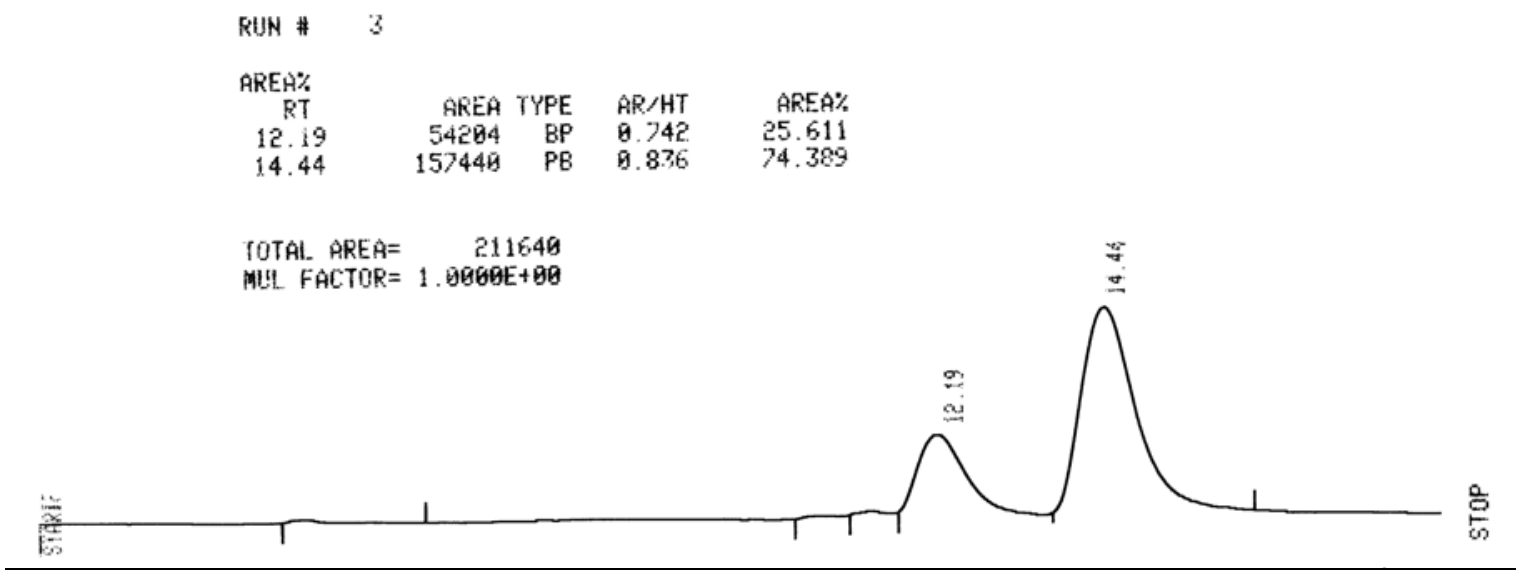




\section{References}

1) Ito, C.; Katsuno, S.; Ruangrungsi, N.; Furukawa, H. Chem. Pharm. Bull. 1998, 46, 344.

2) Wu, T.-S.; Huang, S.-C.; Wu, P.-L. Chem. Pharm. Bull. 1998, 46, 1459 


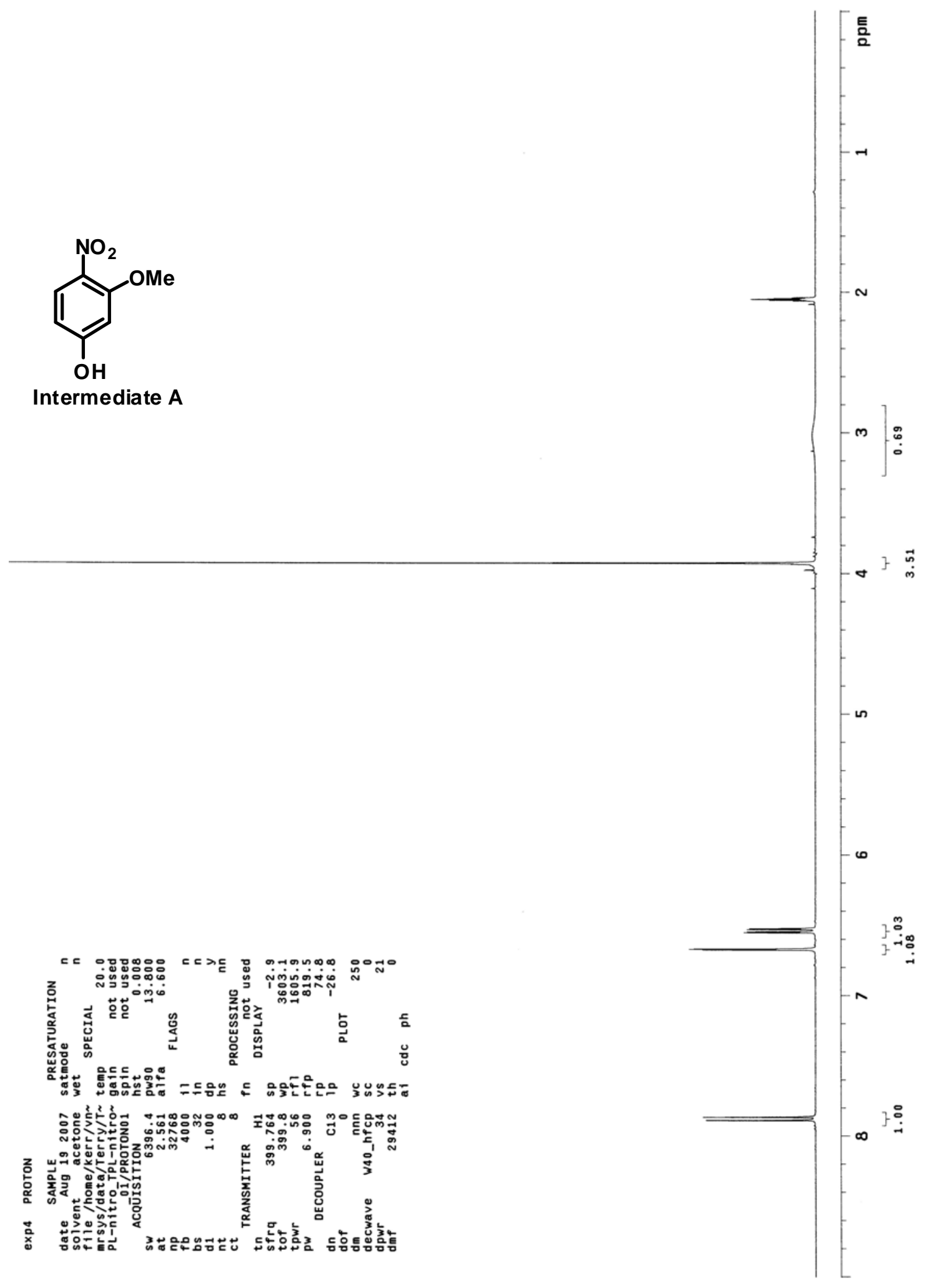

S-15 


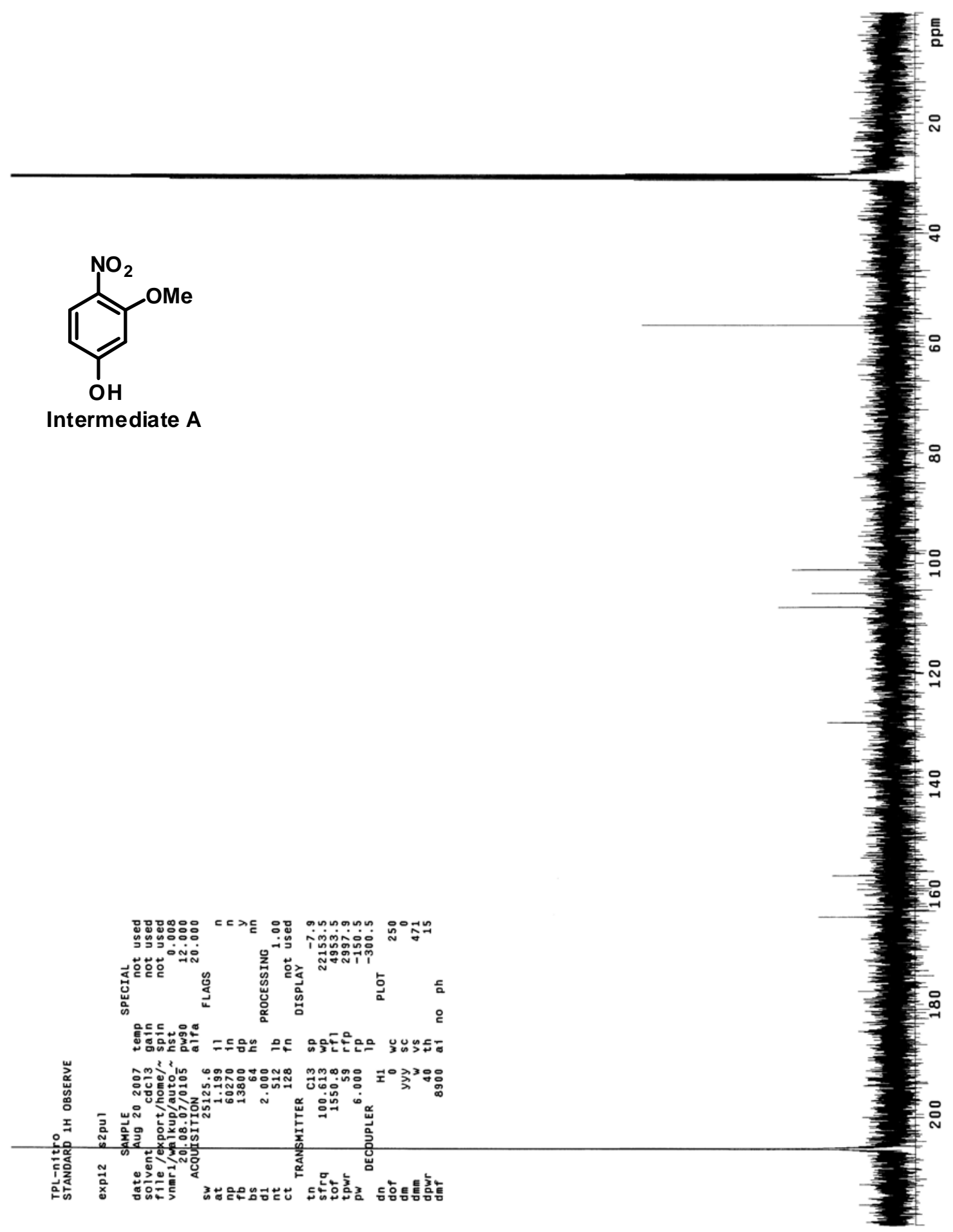

S-16 


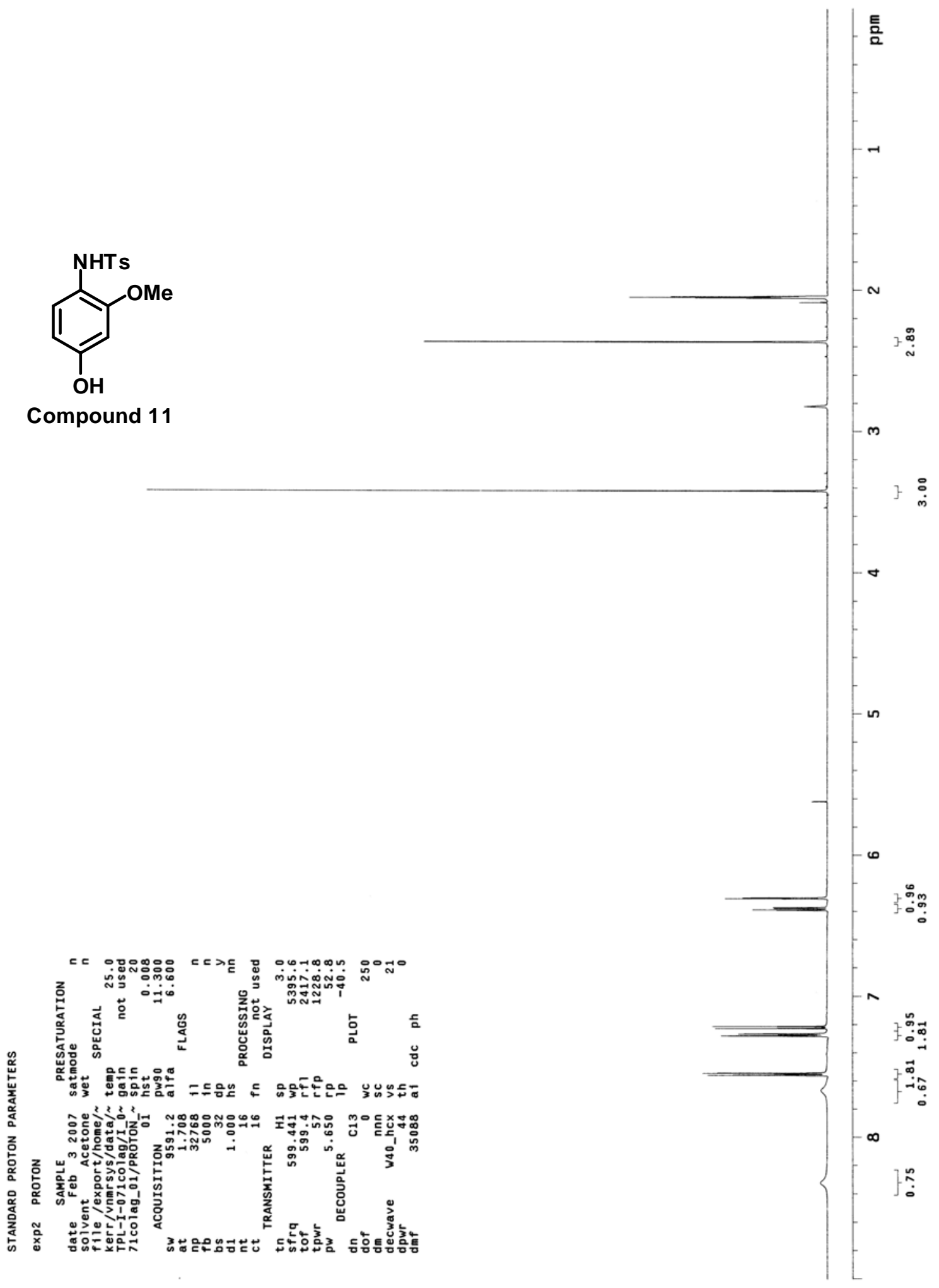




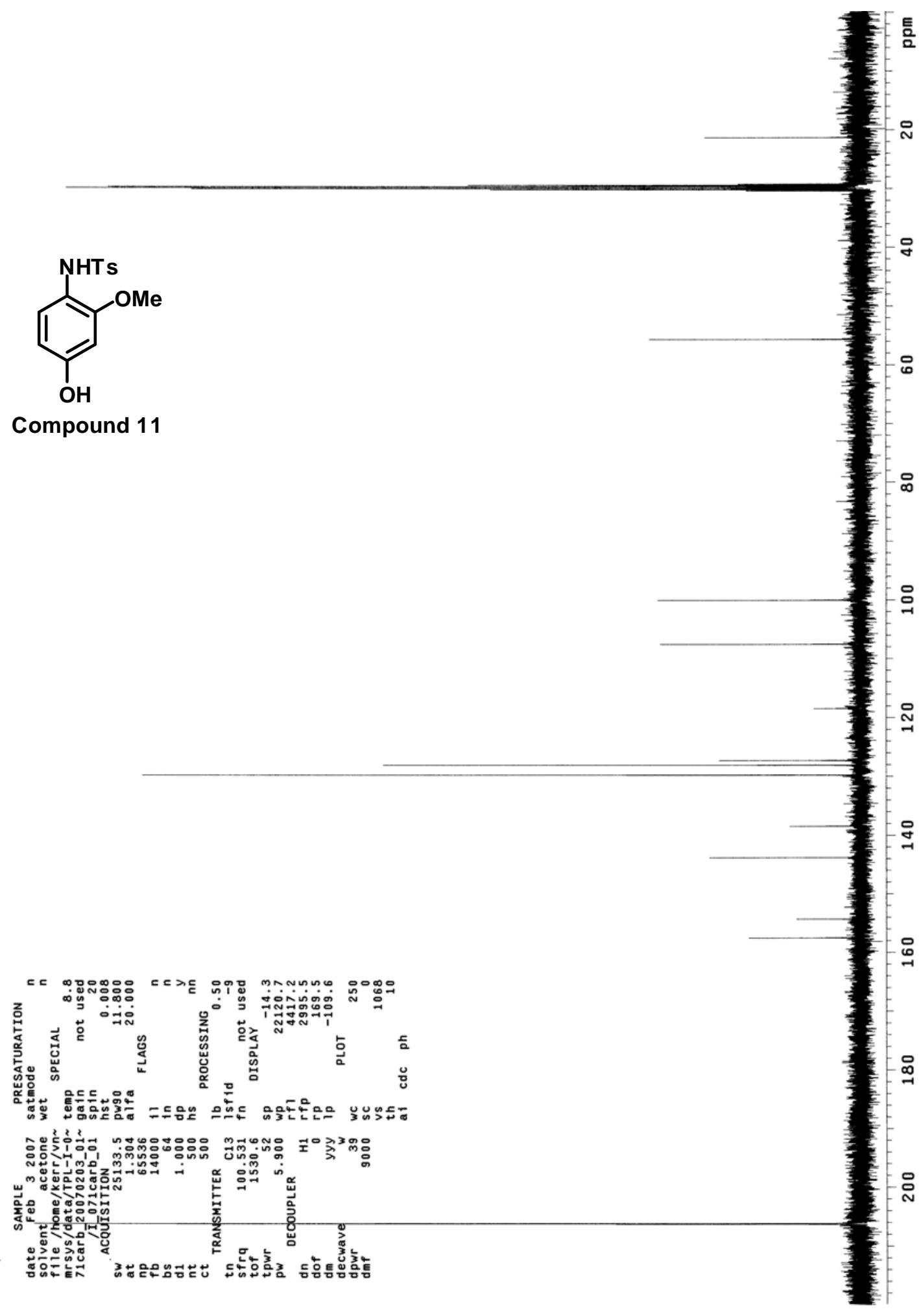




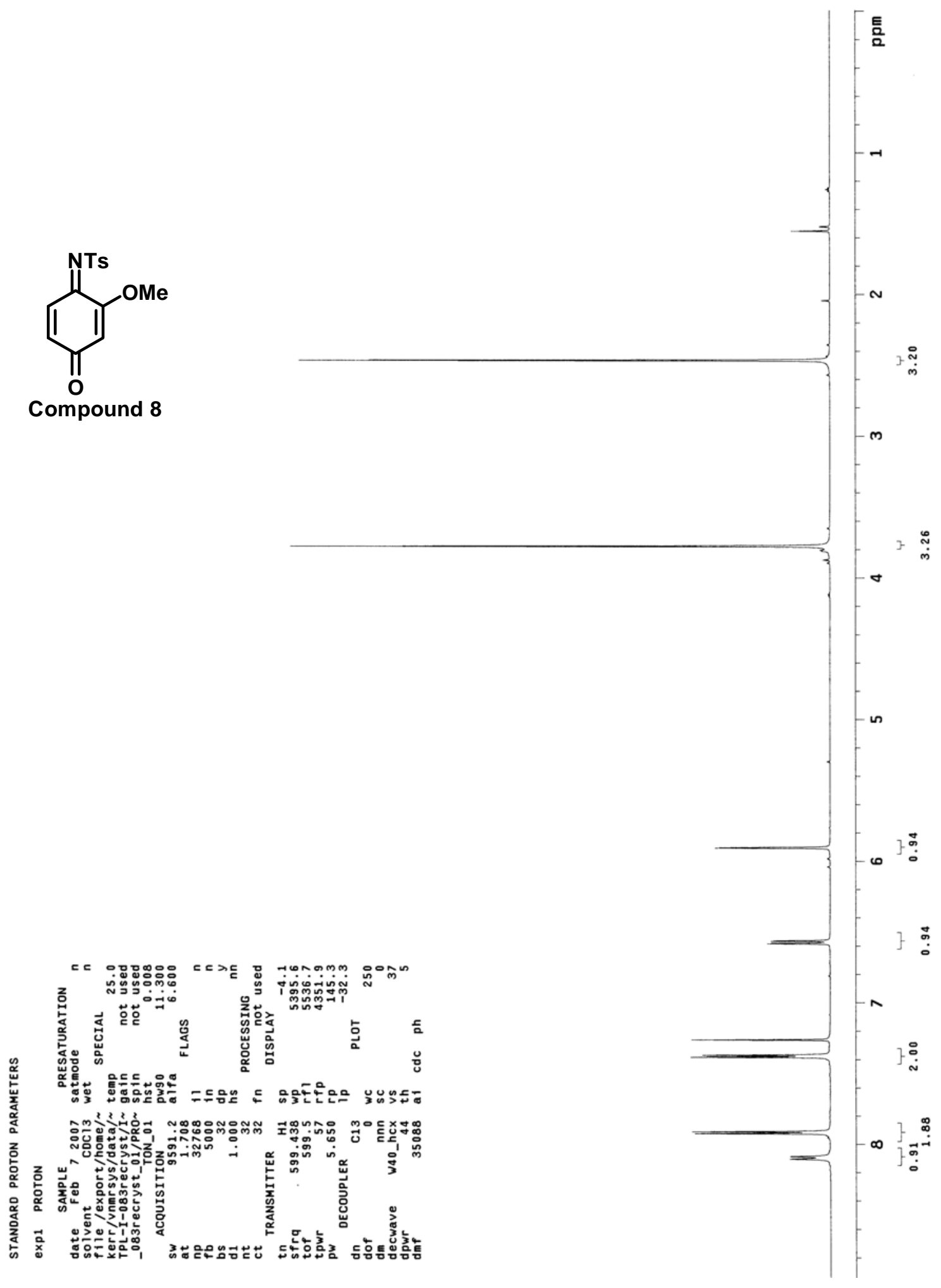




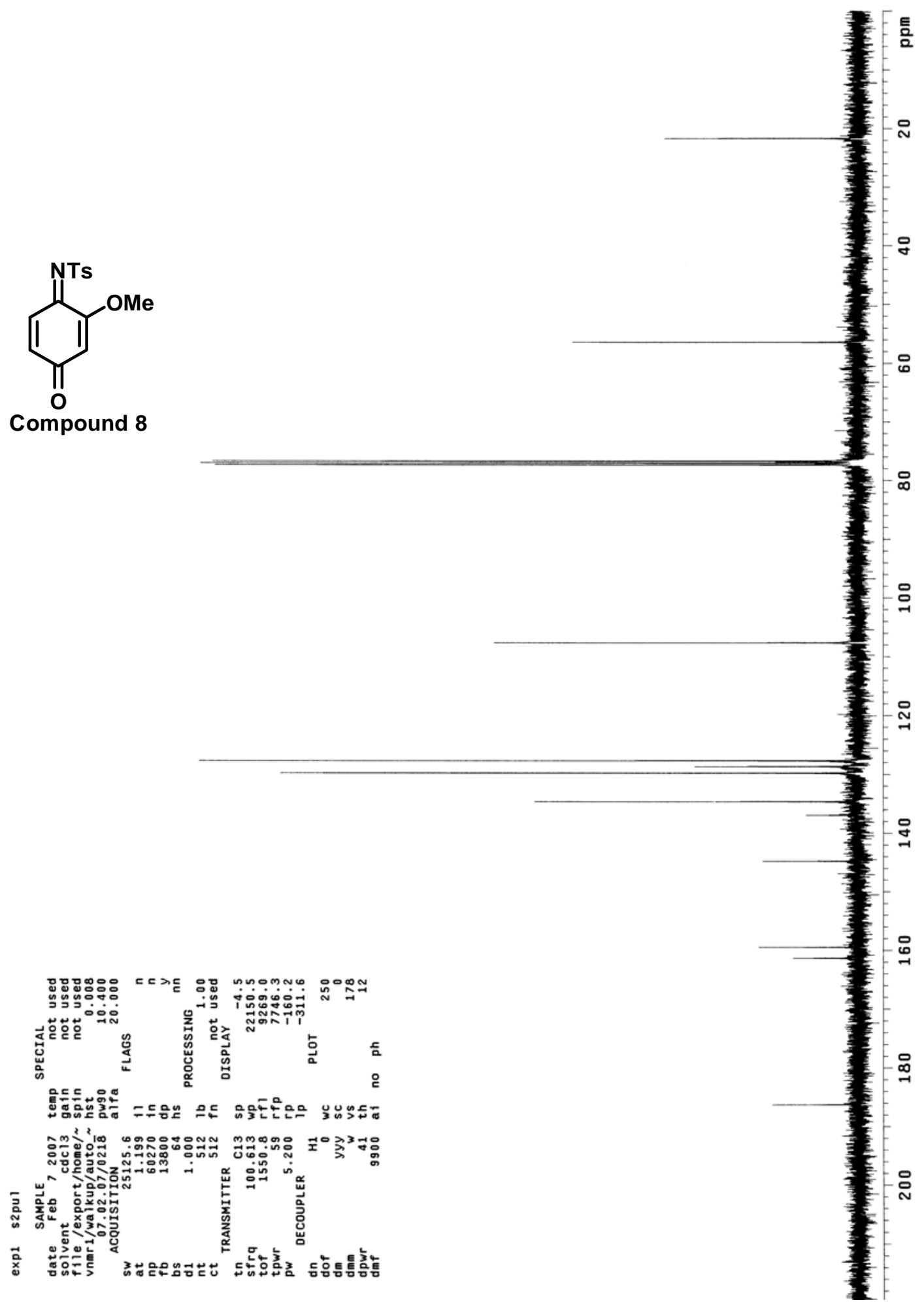




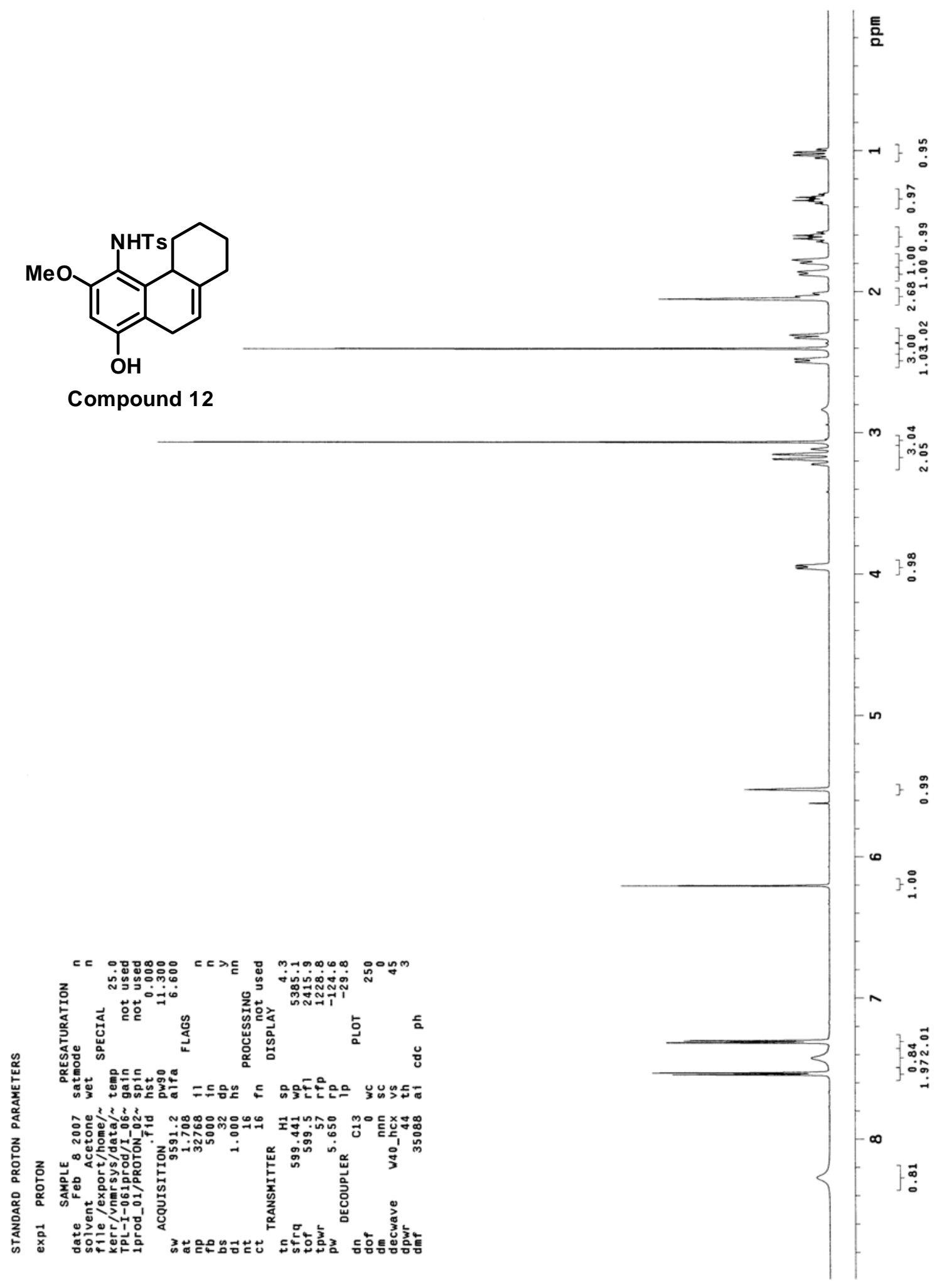



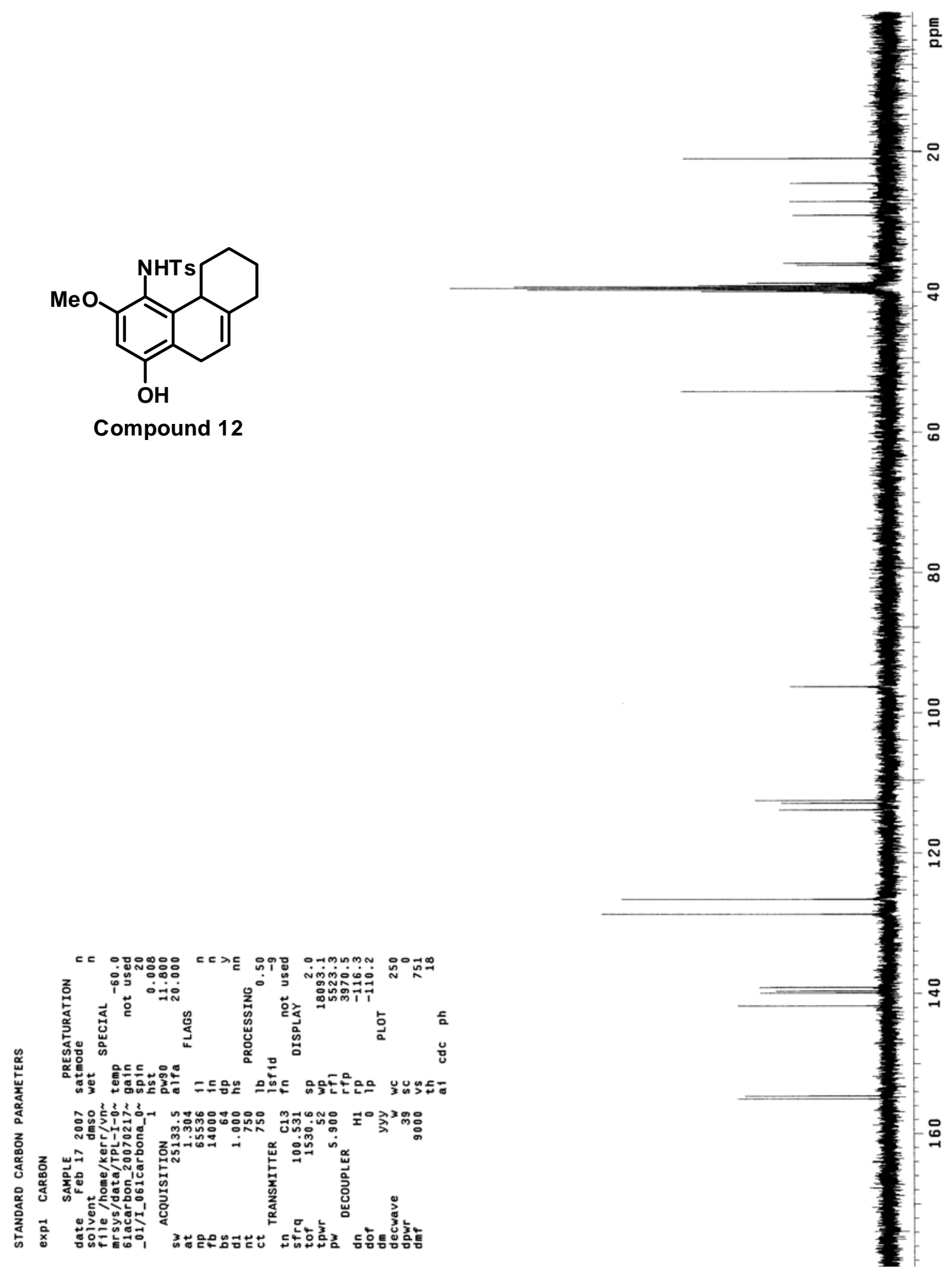


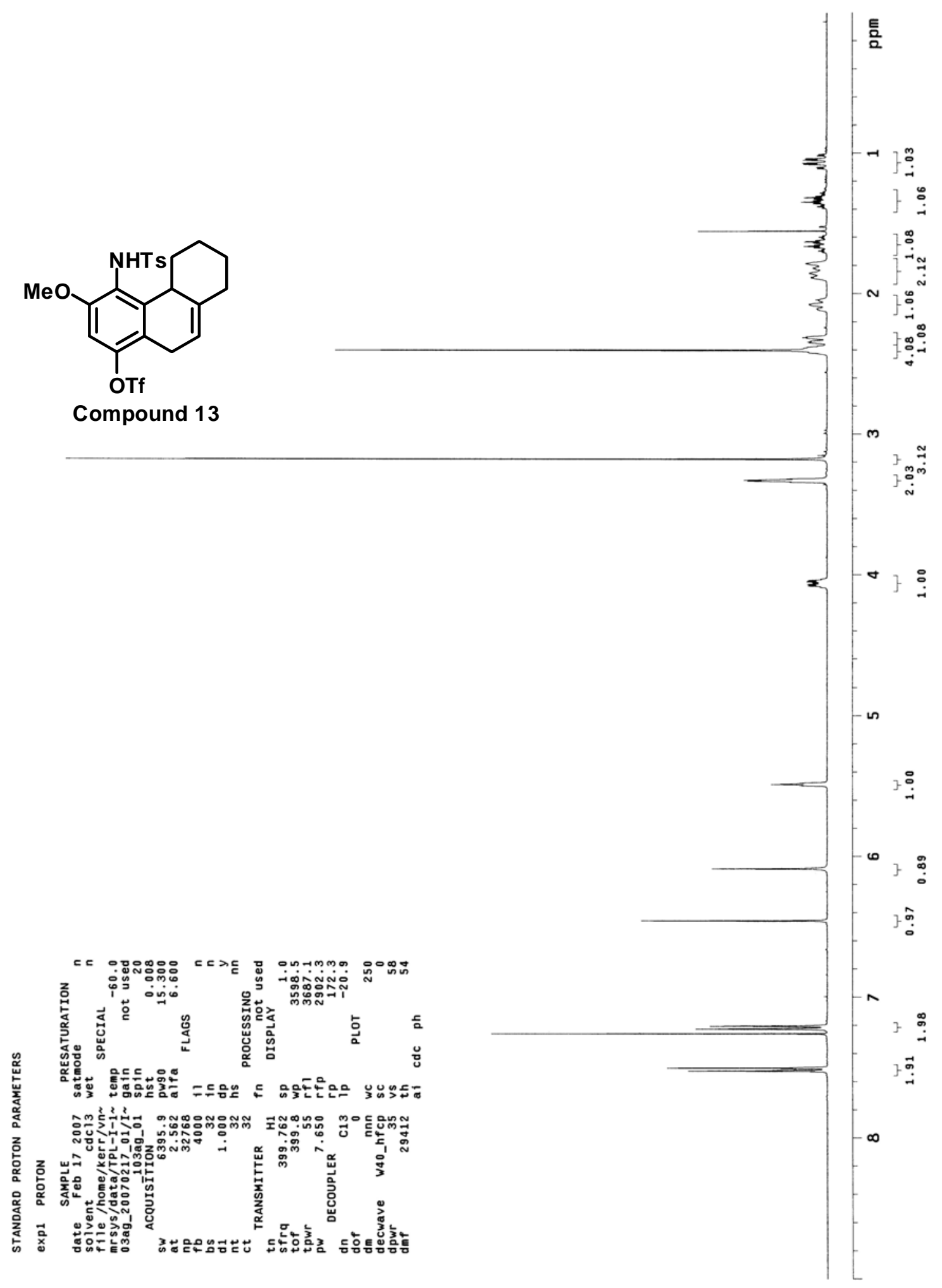



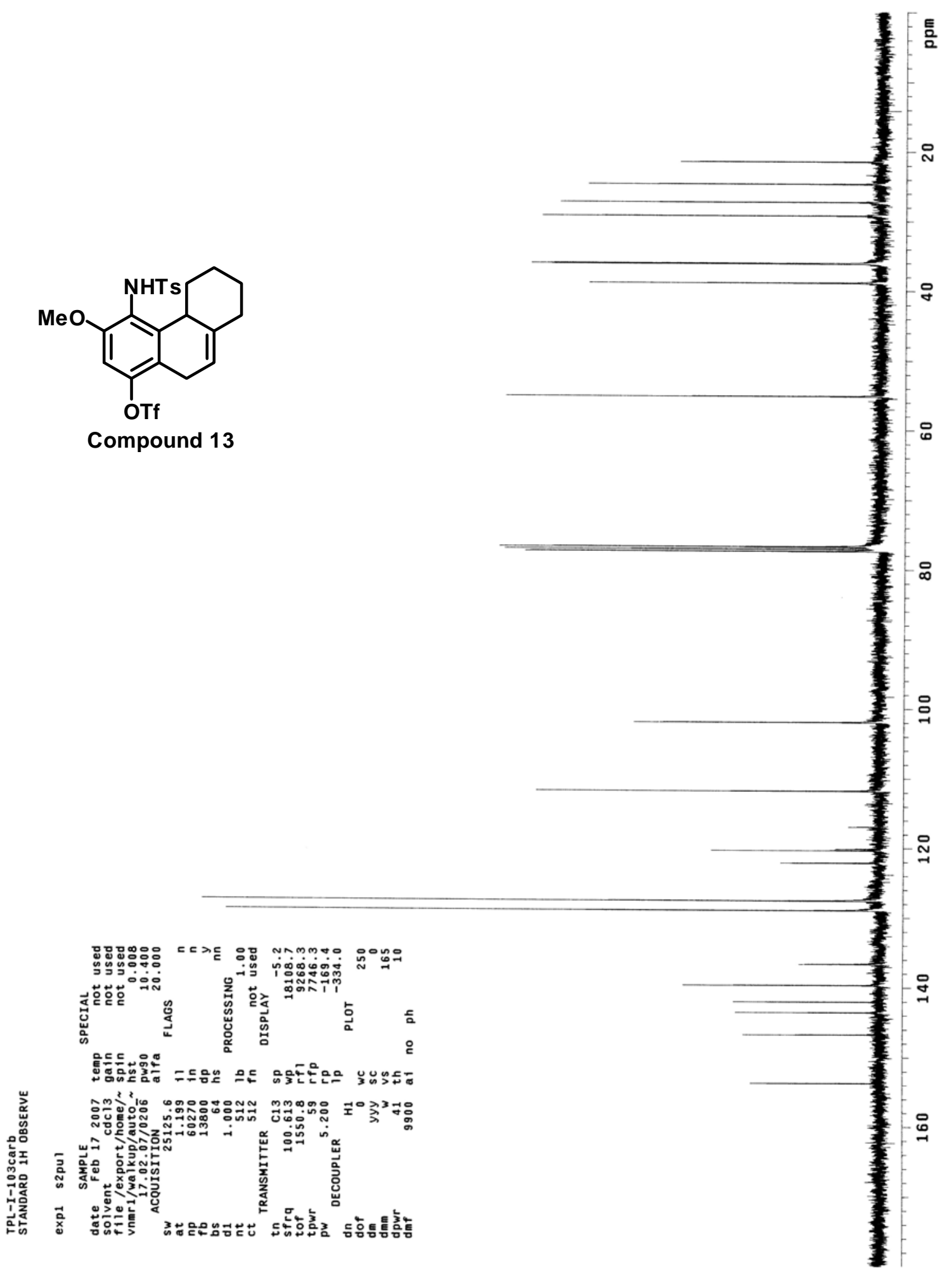


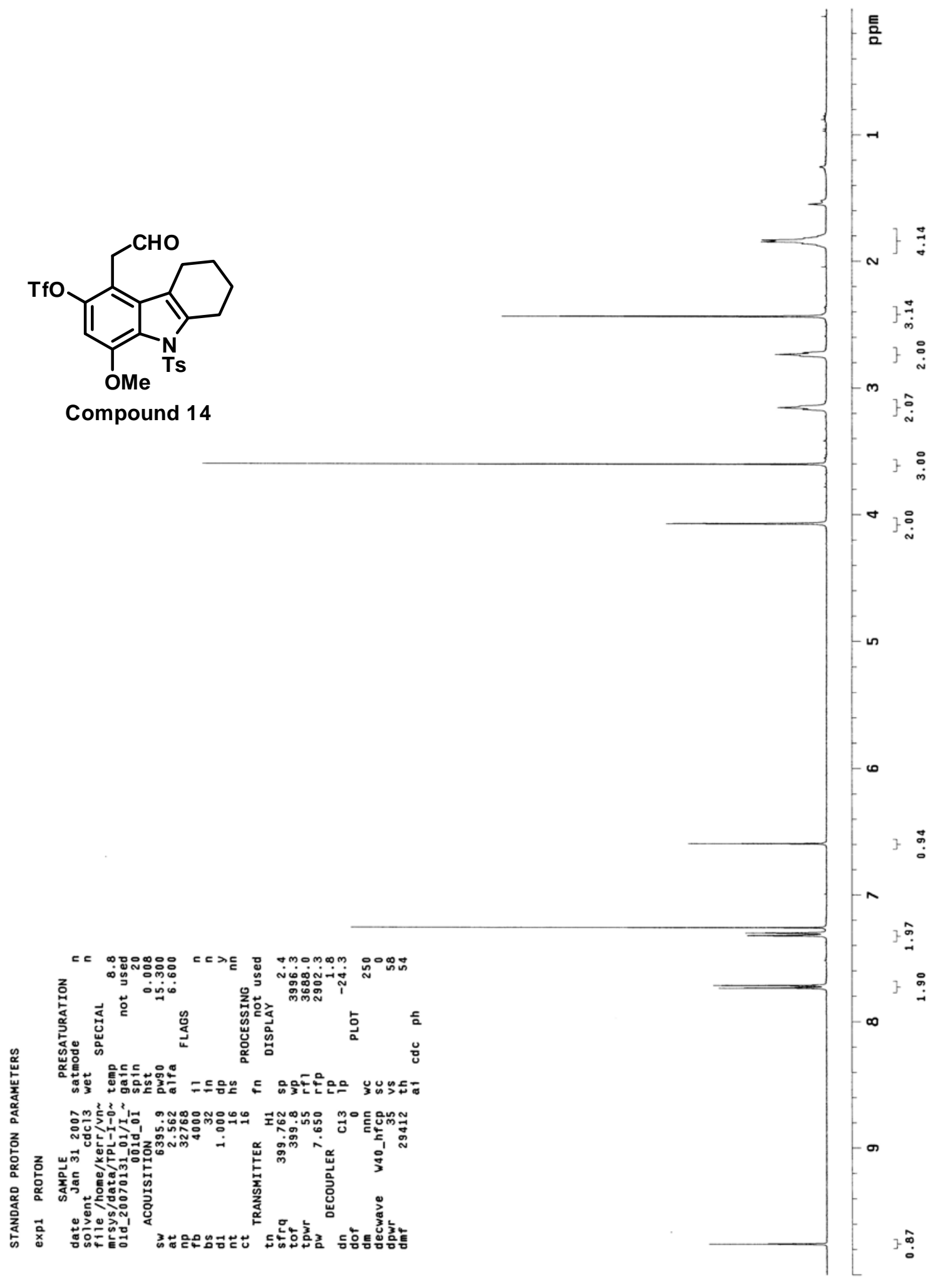



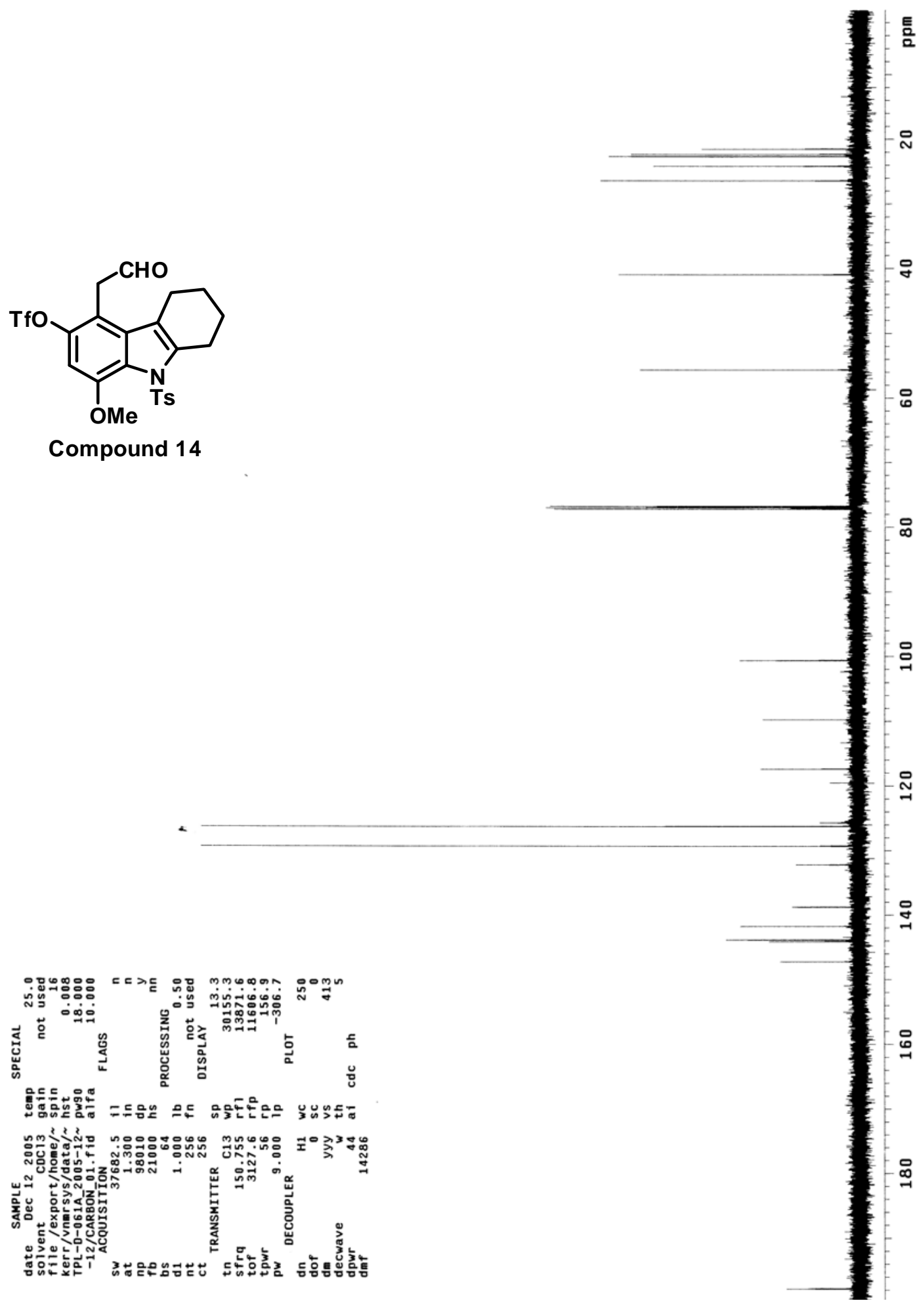

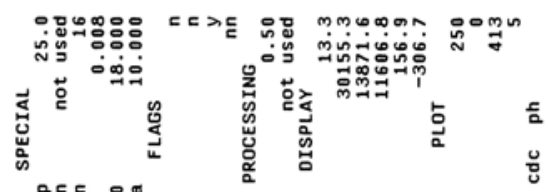

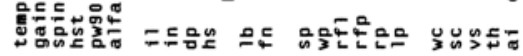

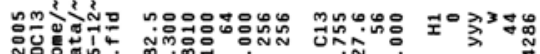

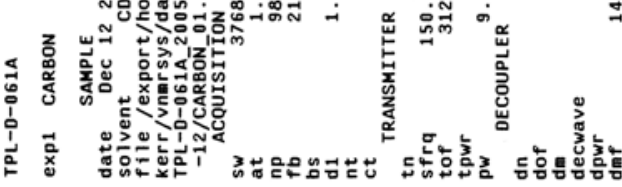




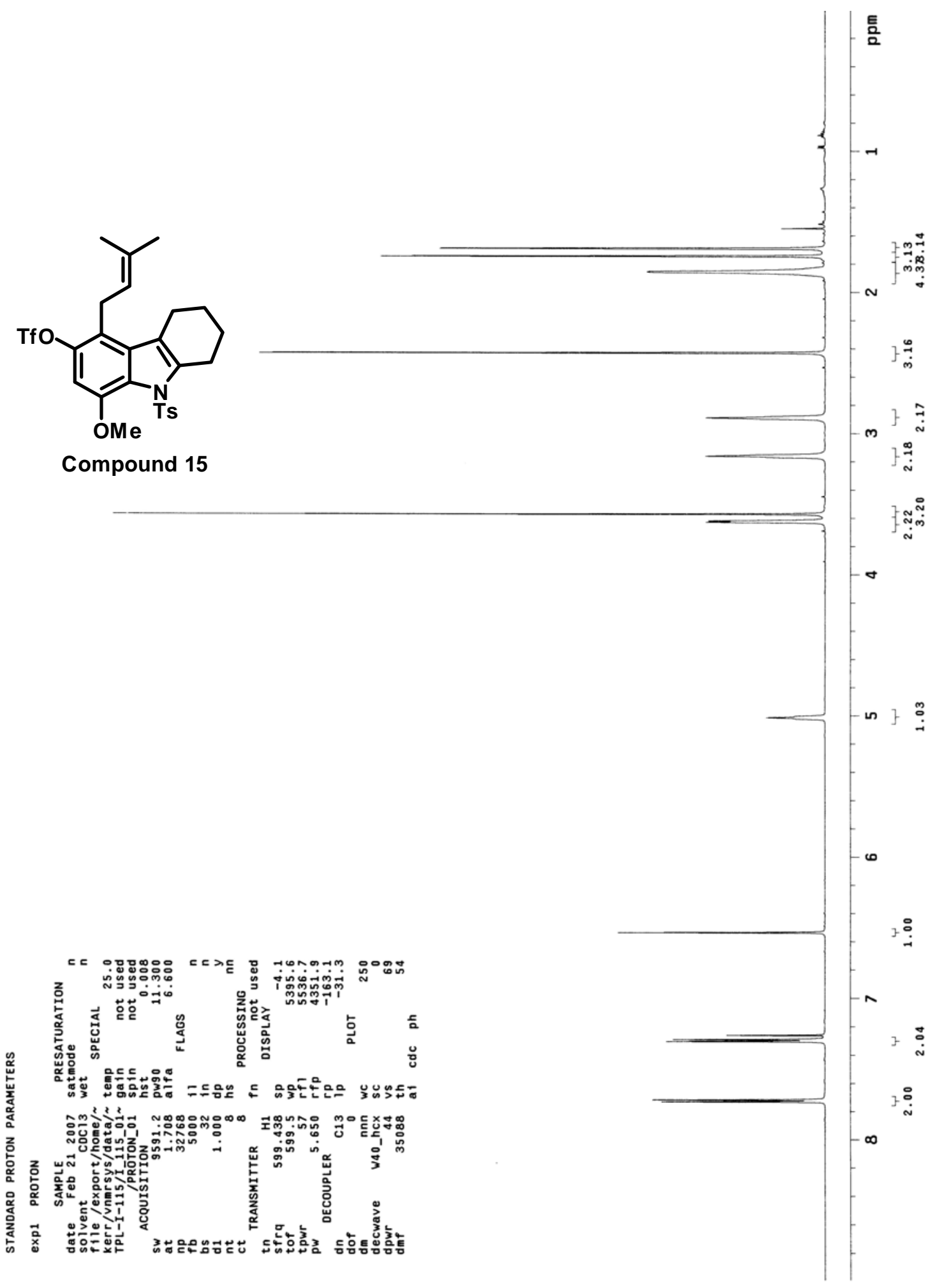




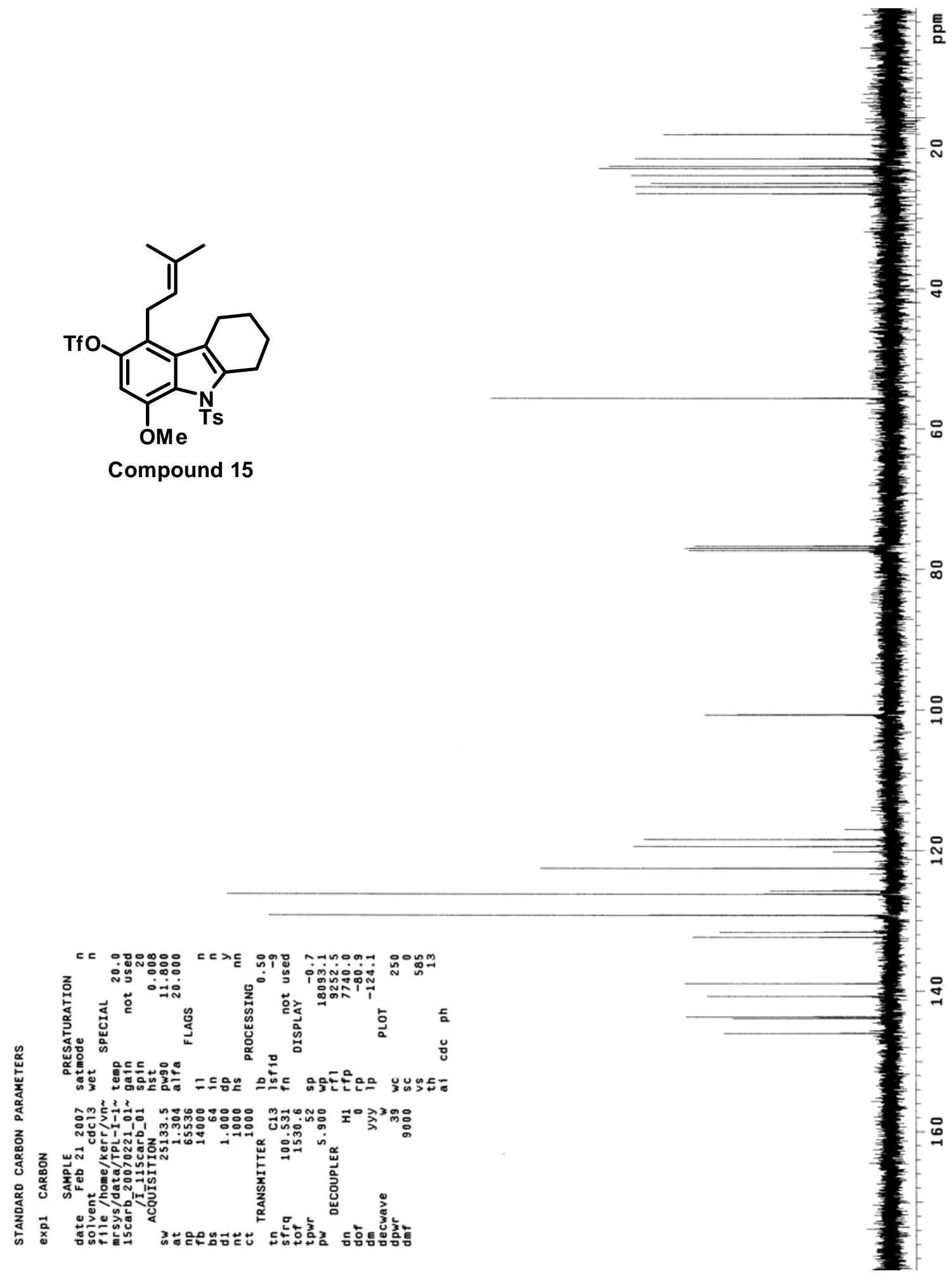




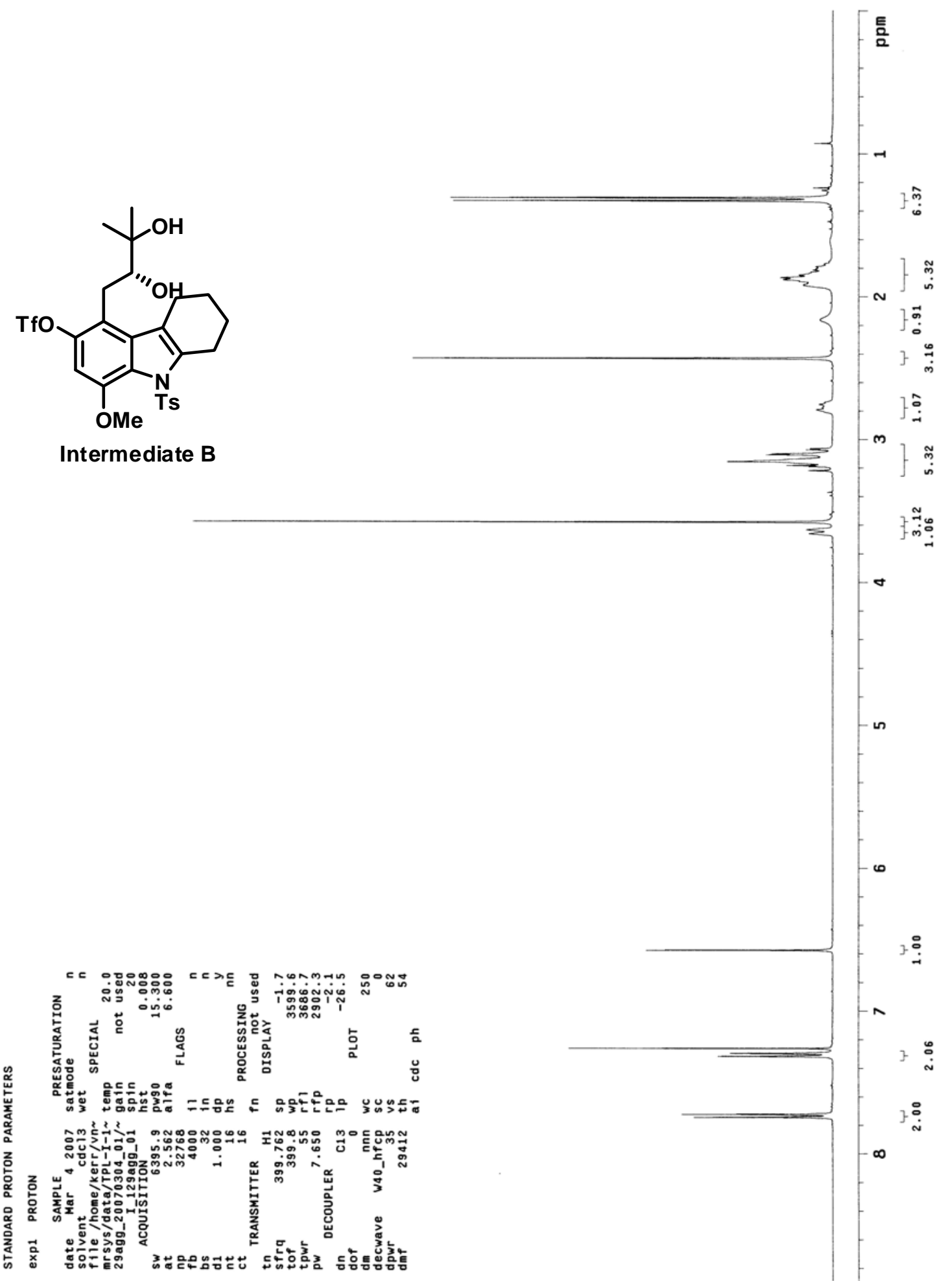



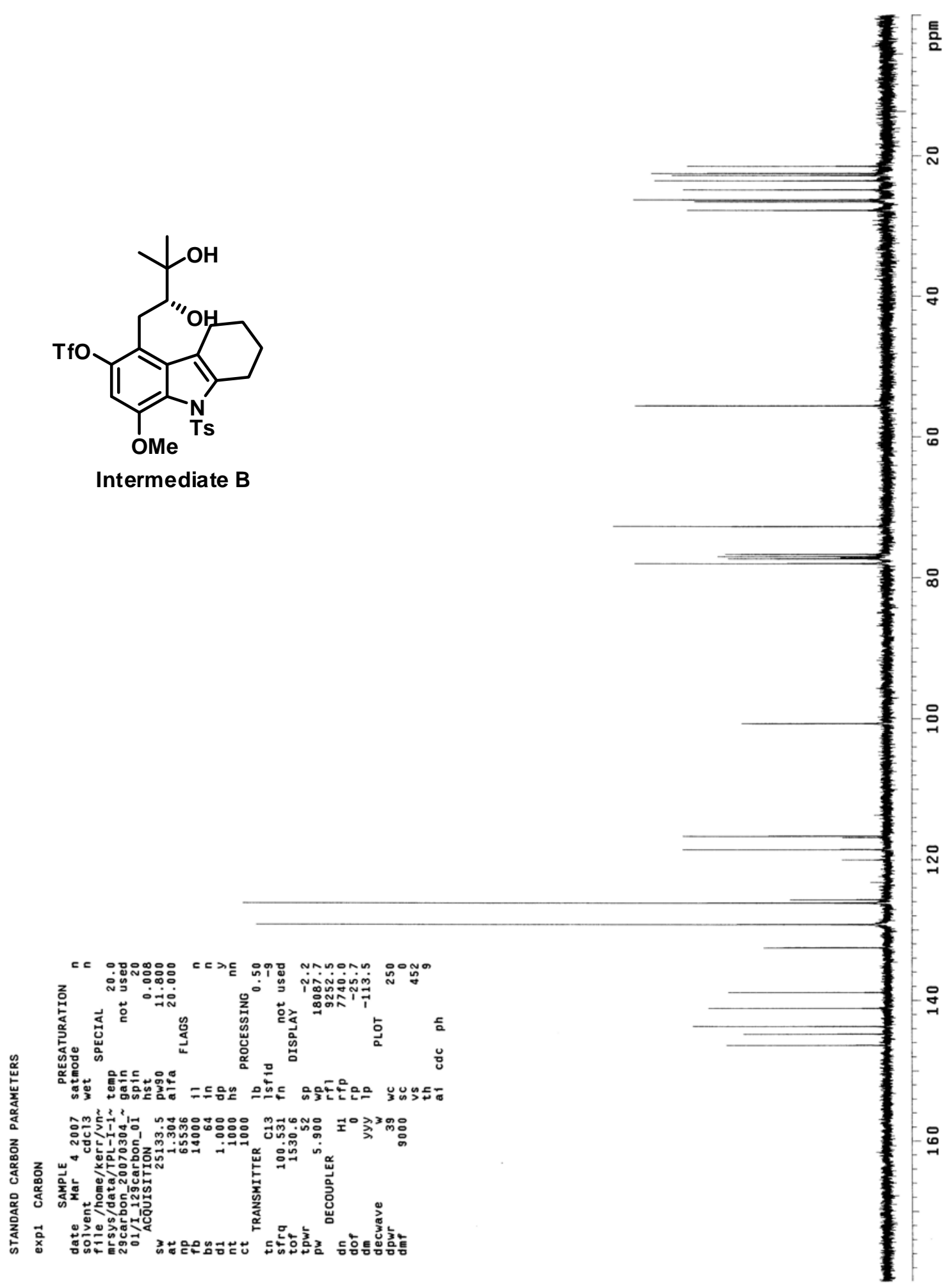


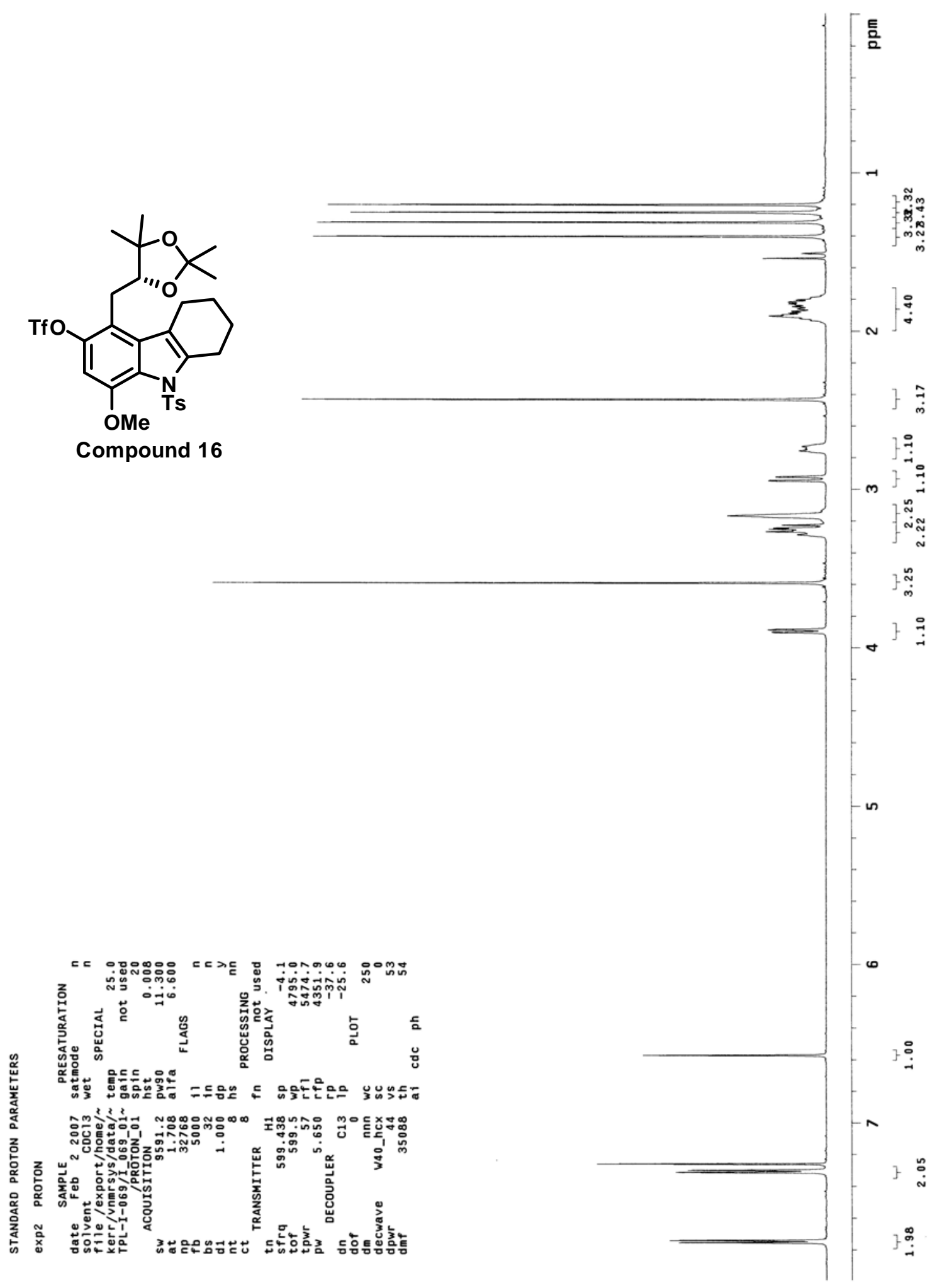



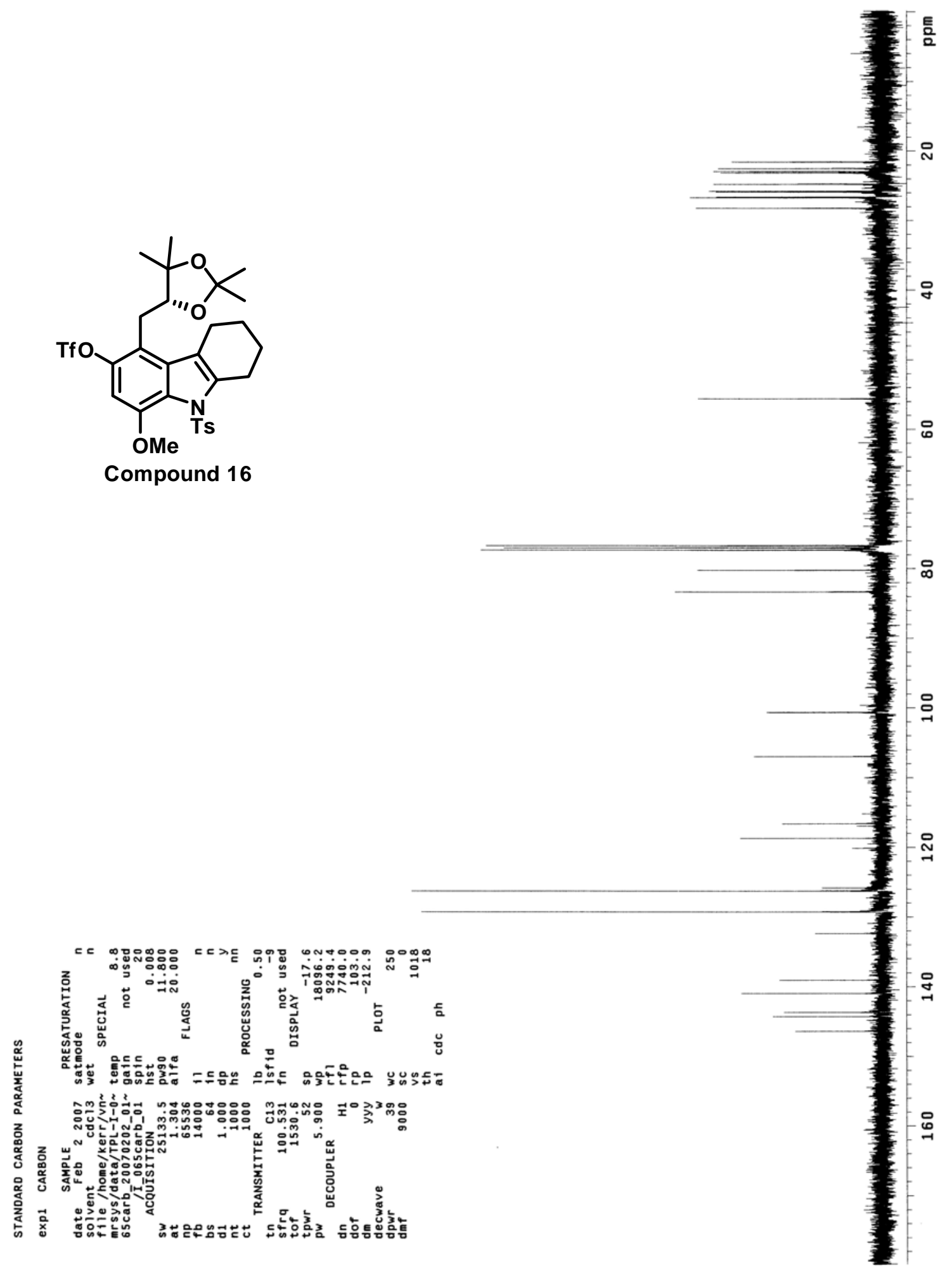


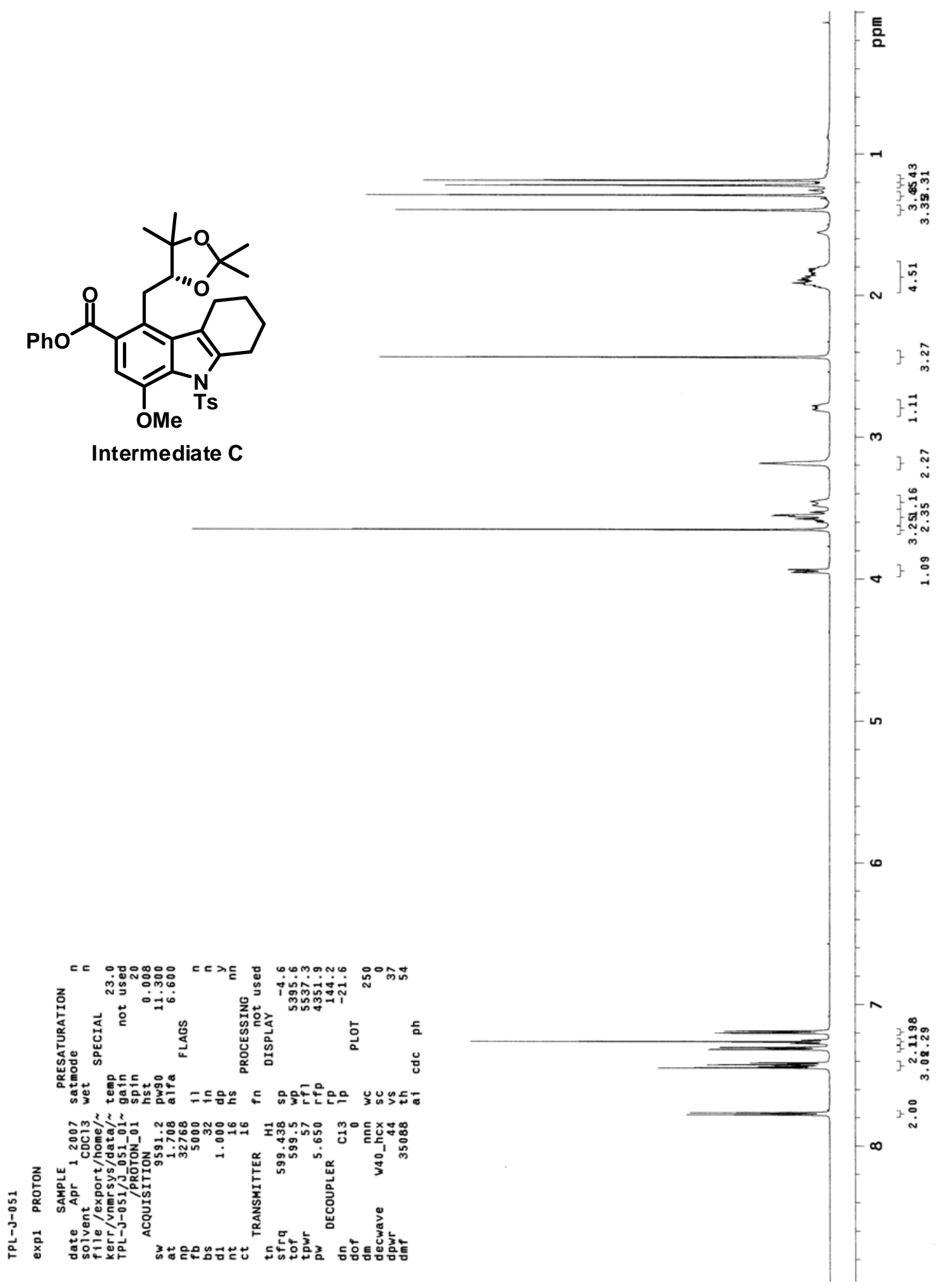



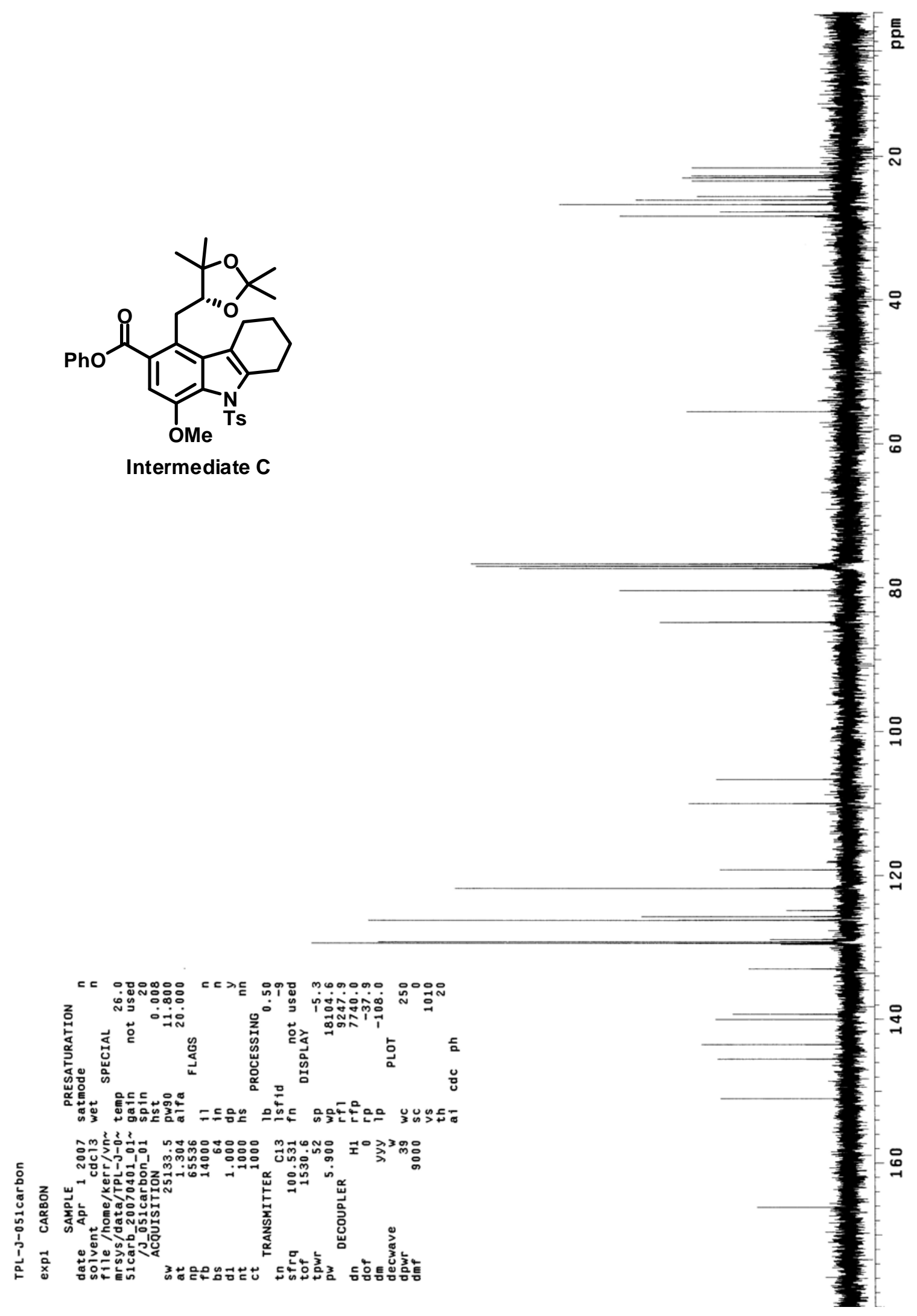


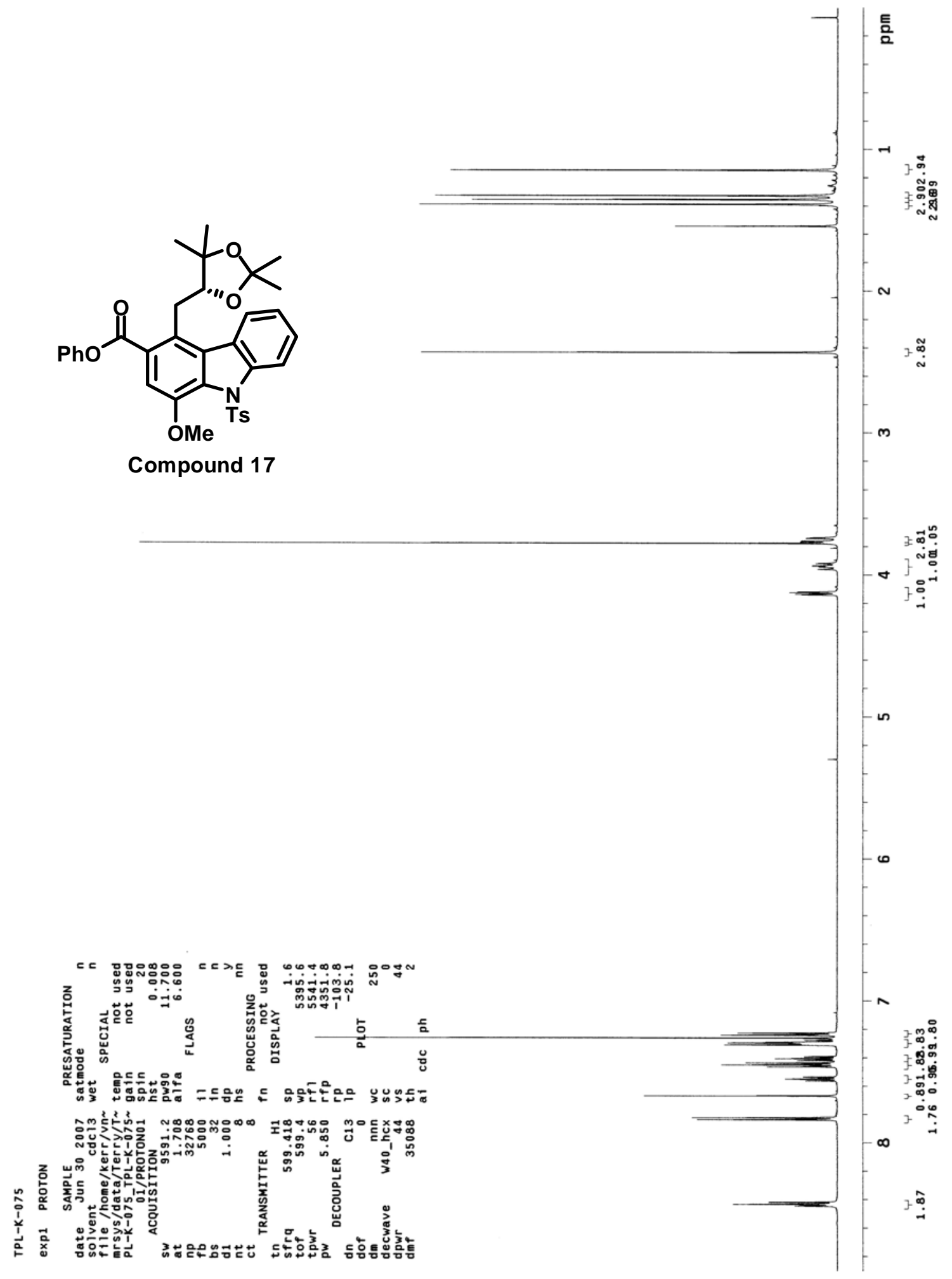



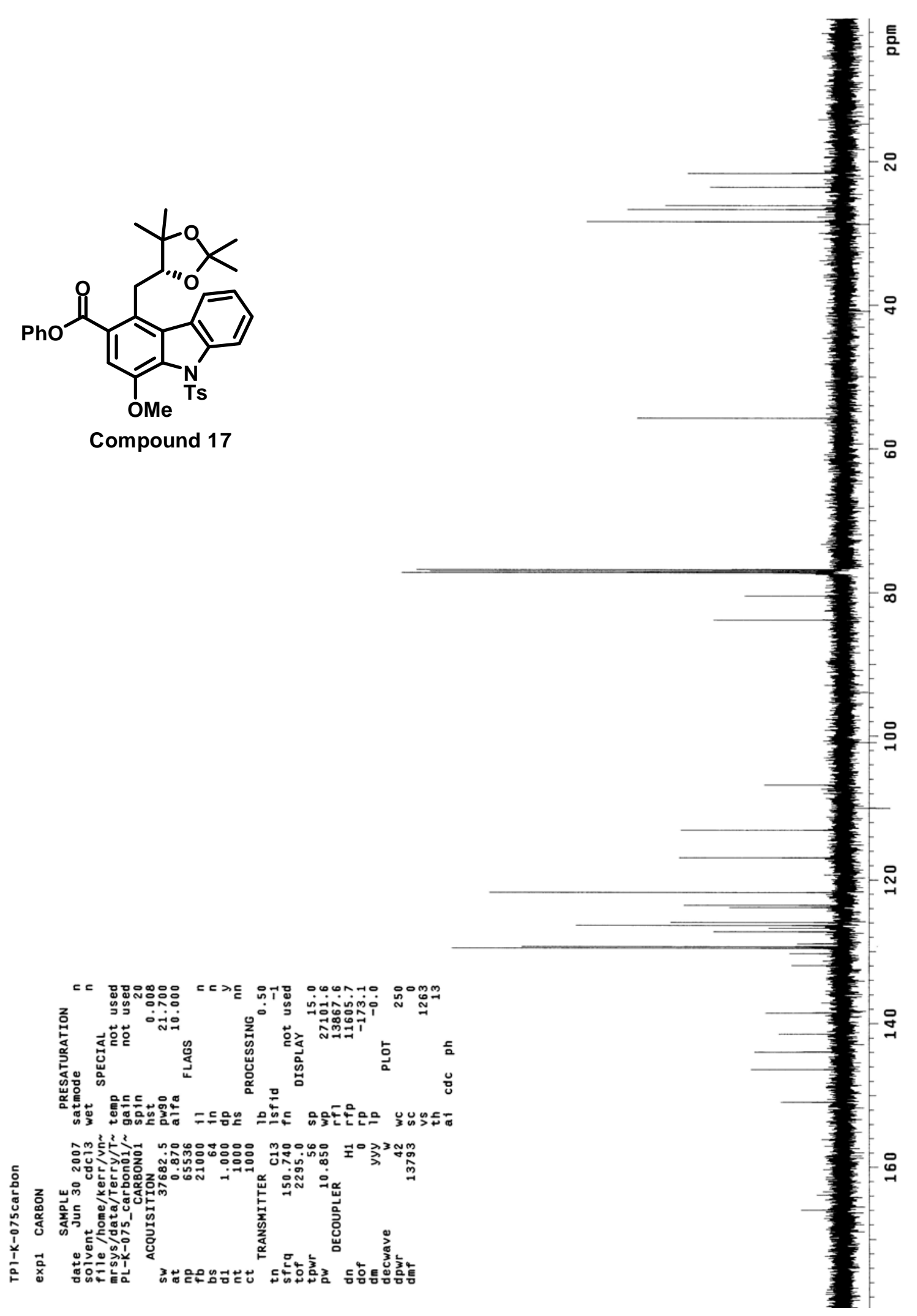


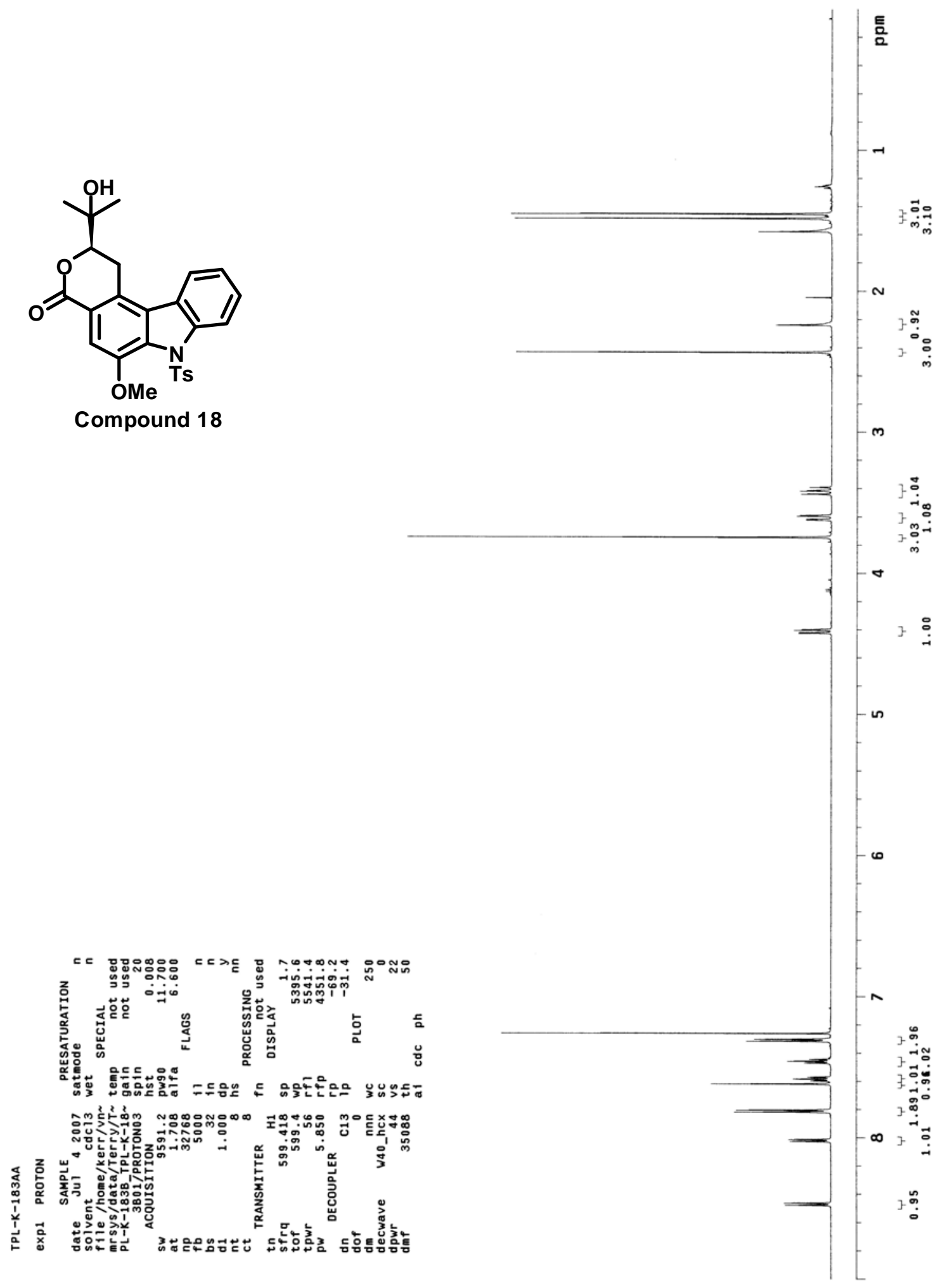




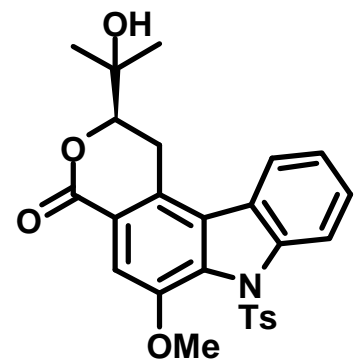

Compound 18
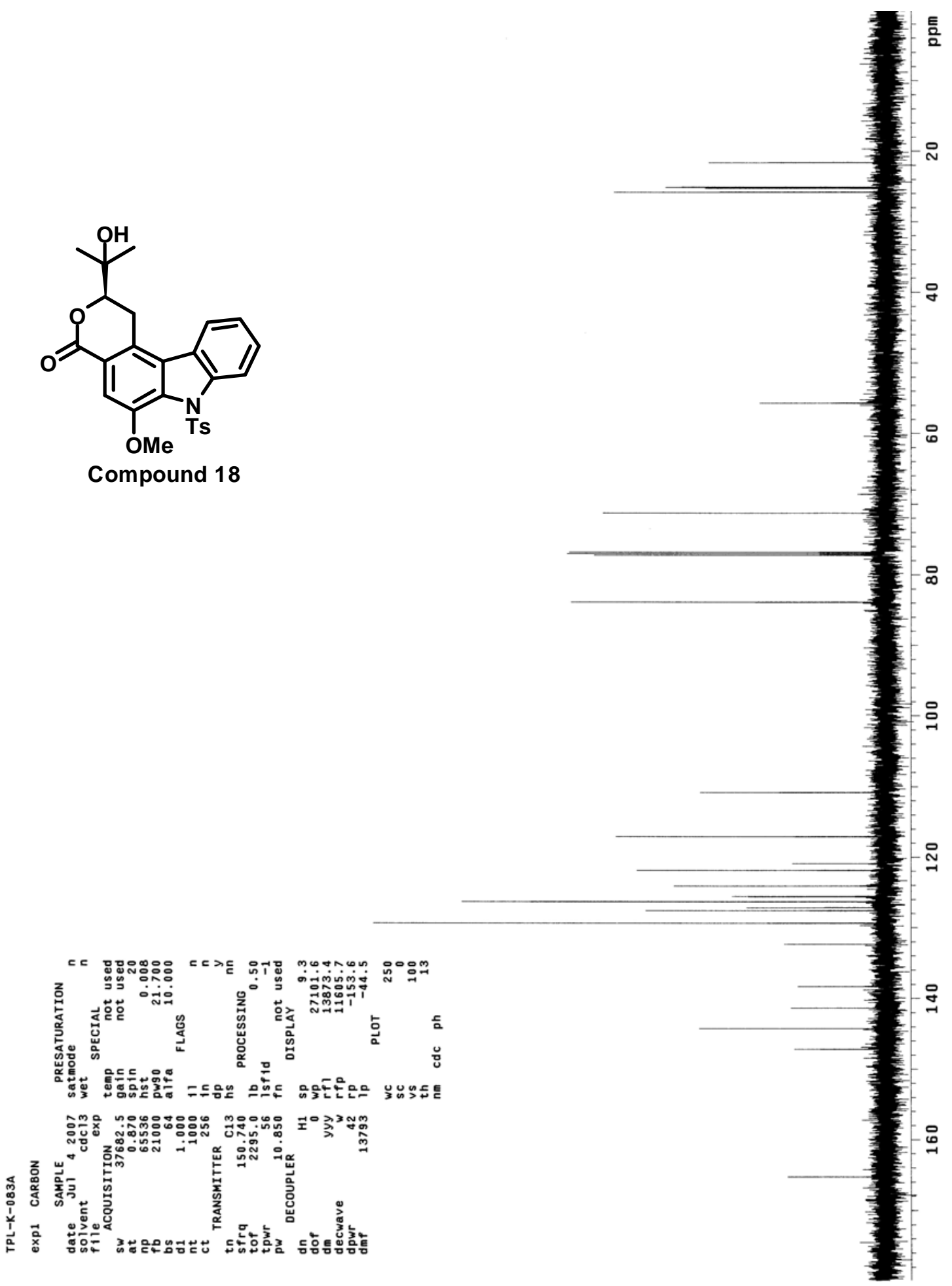


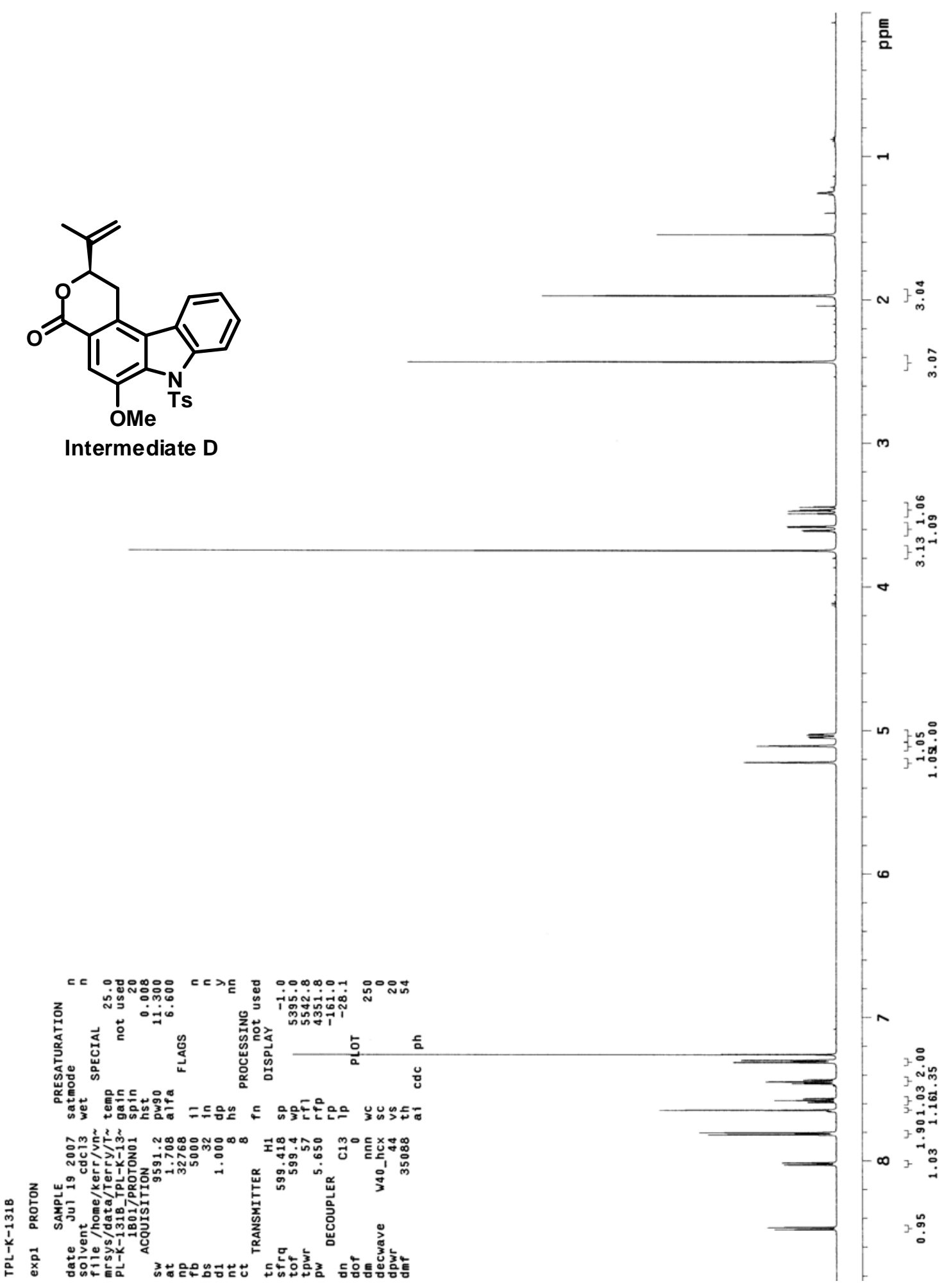




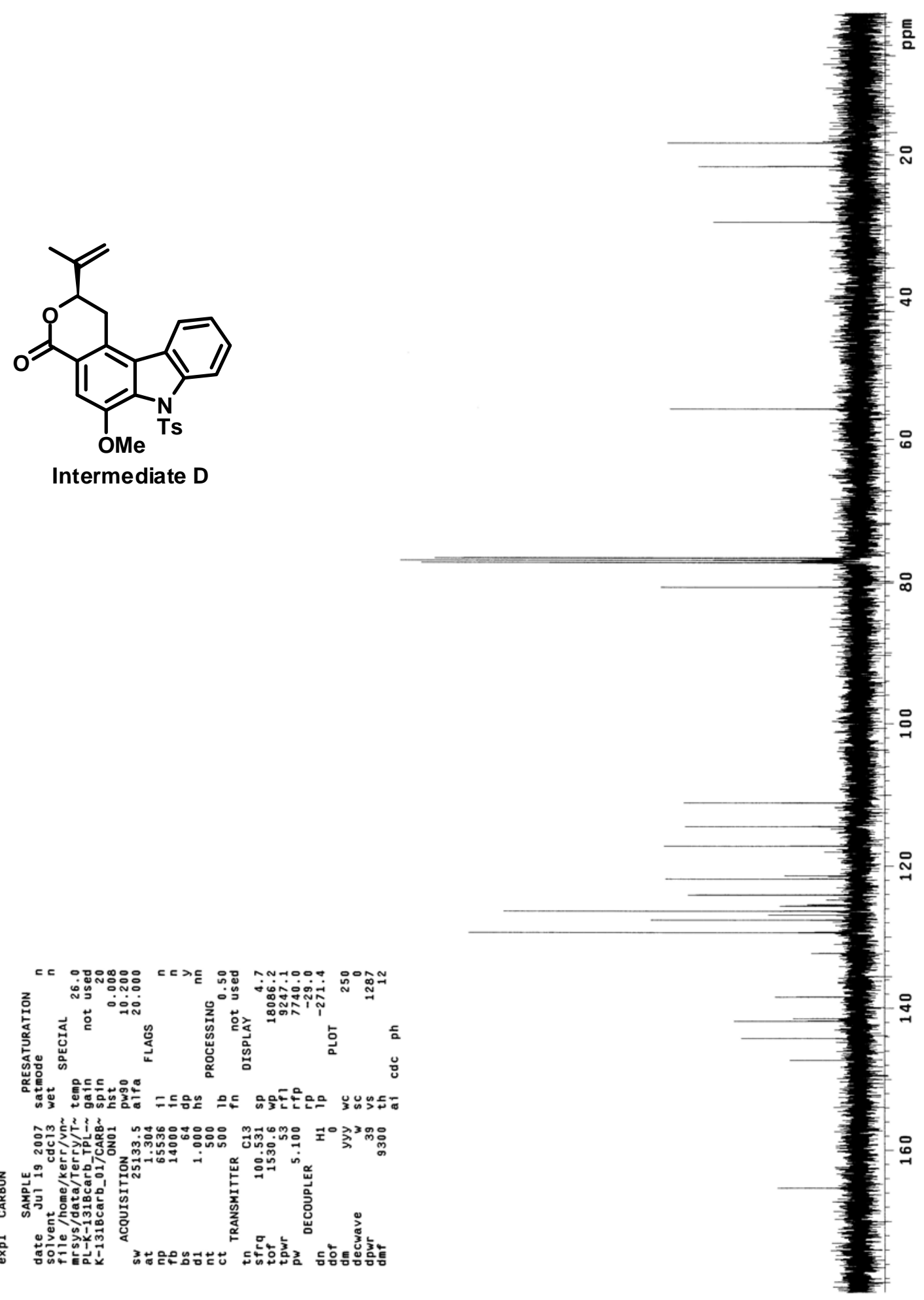




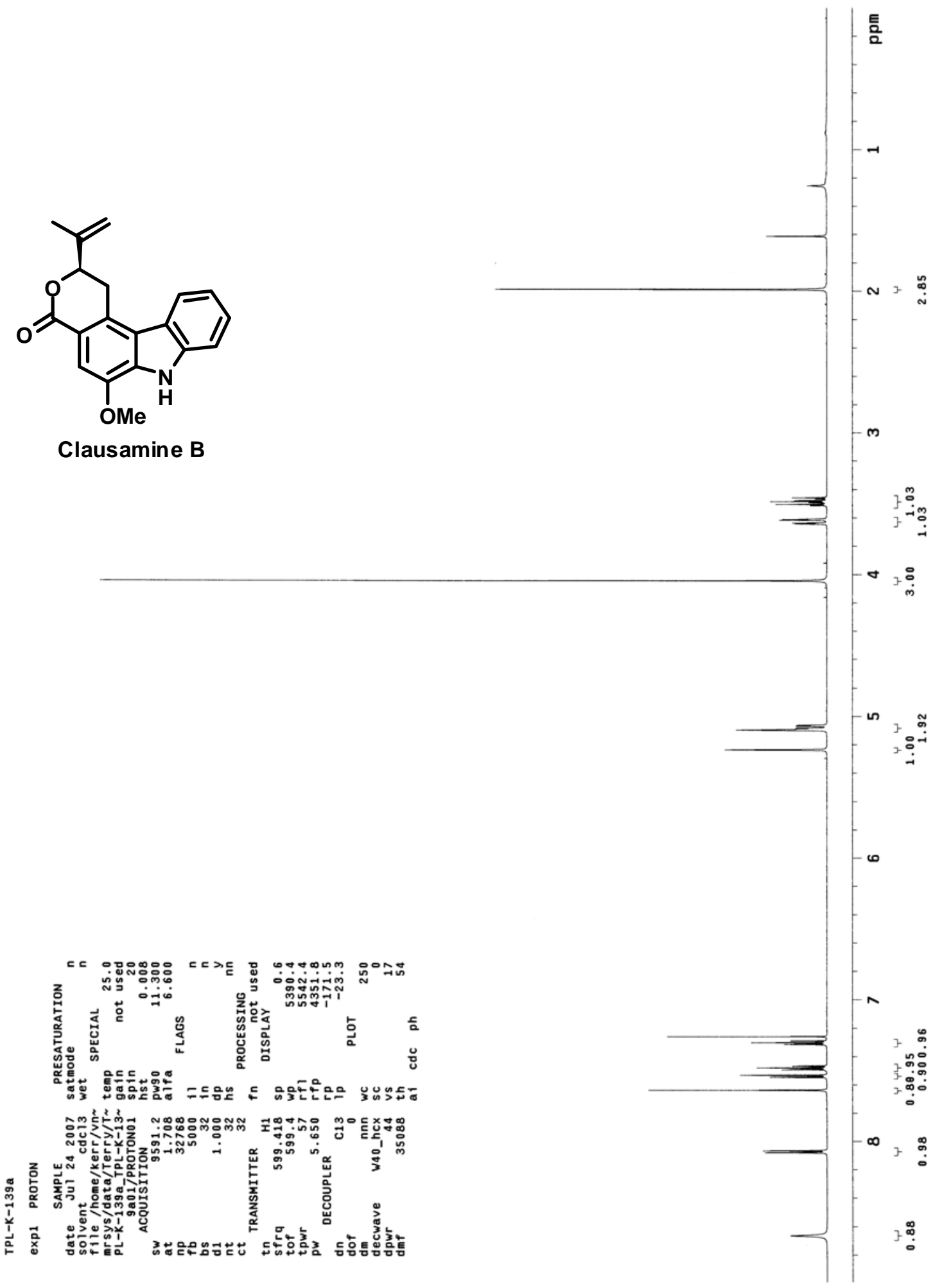




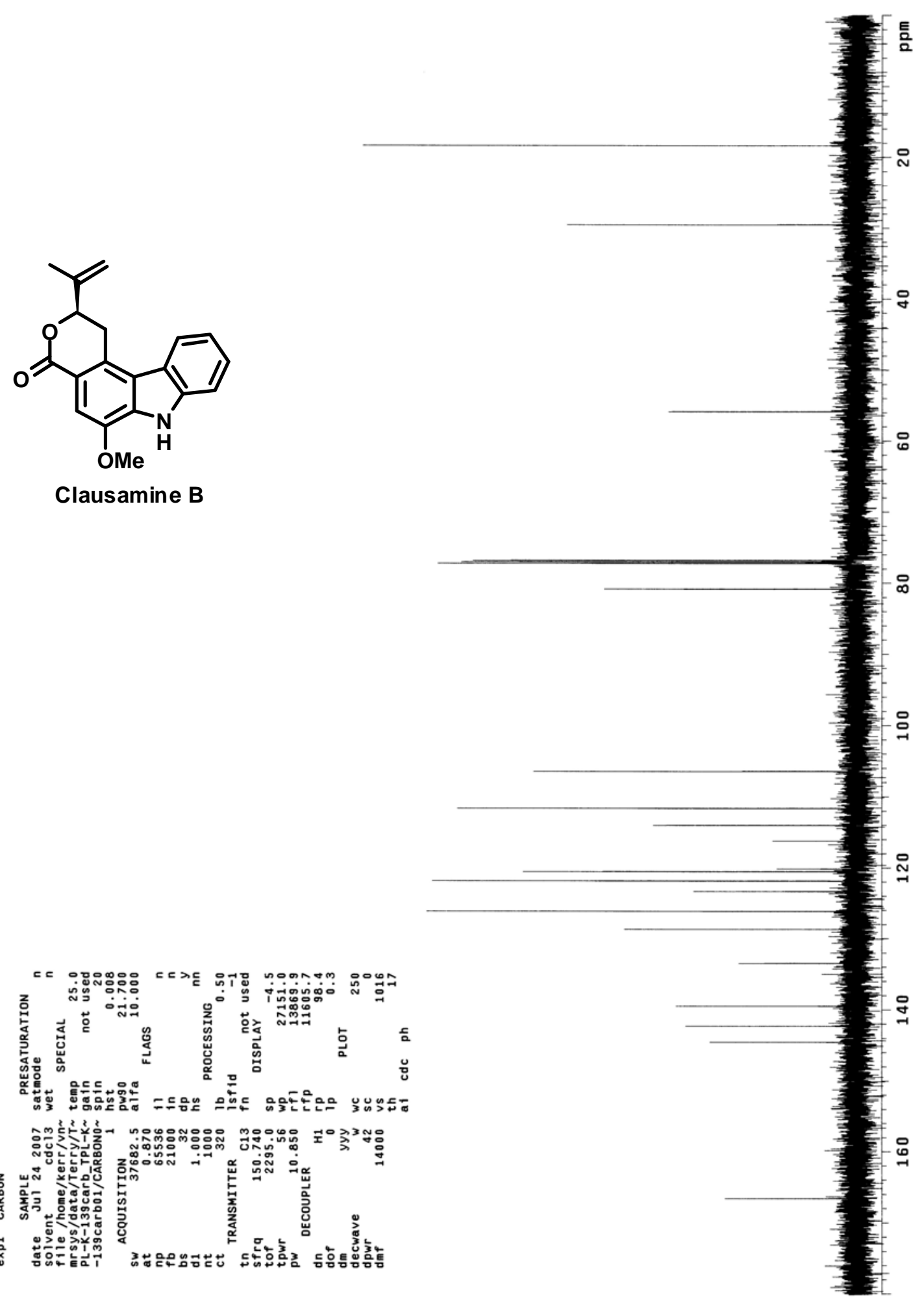




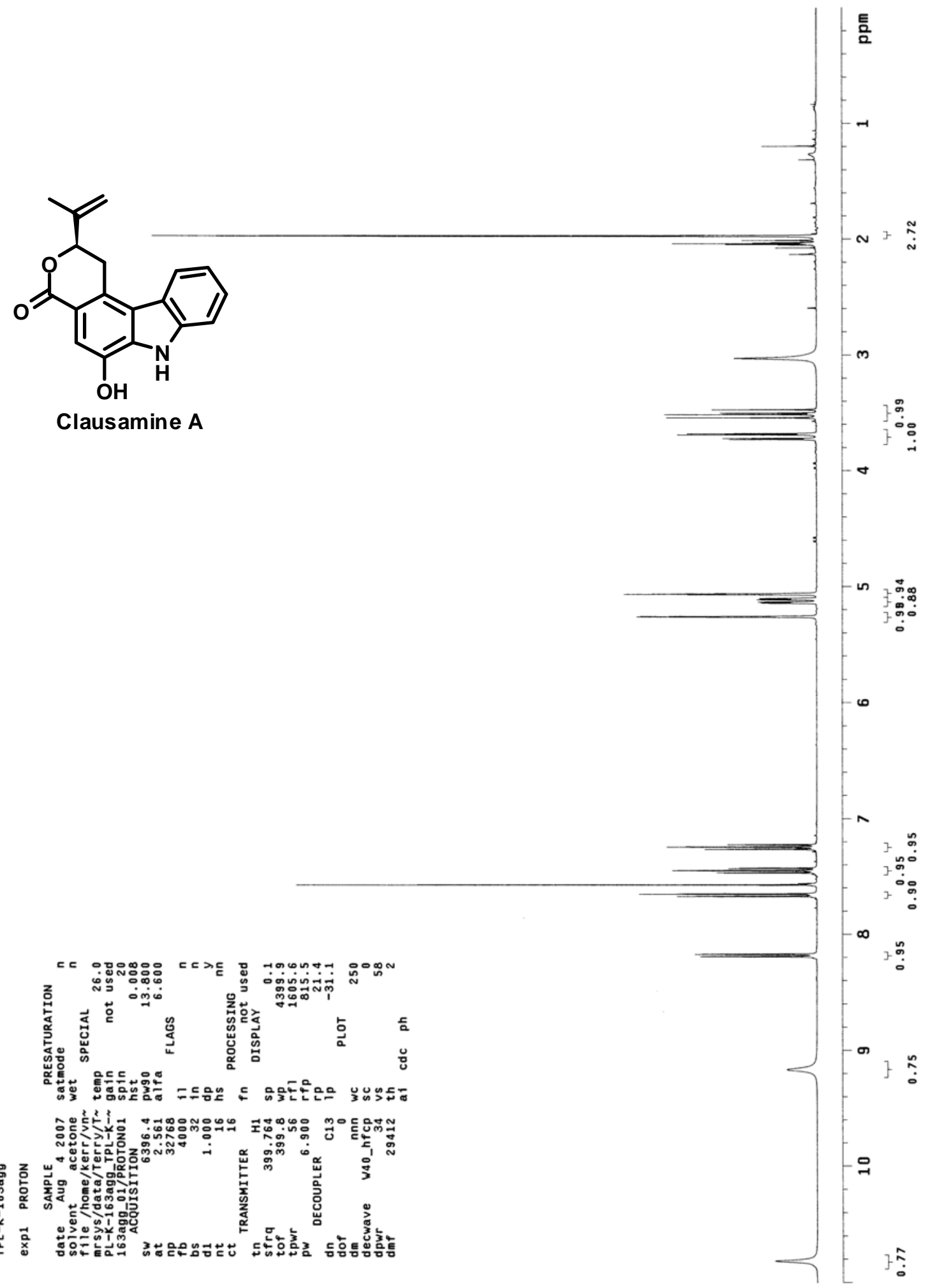




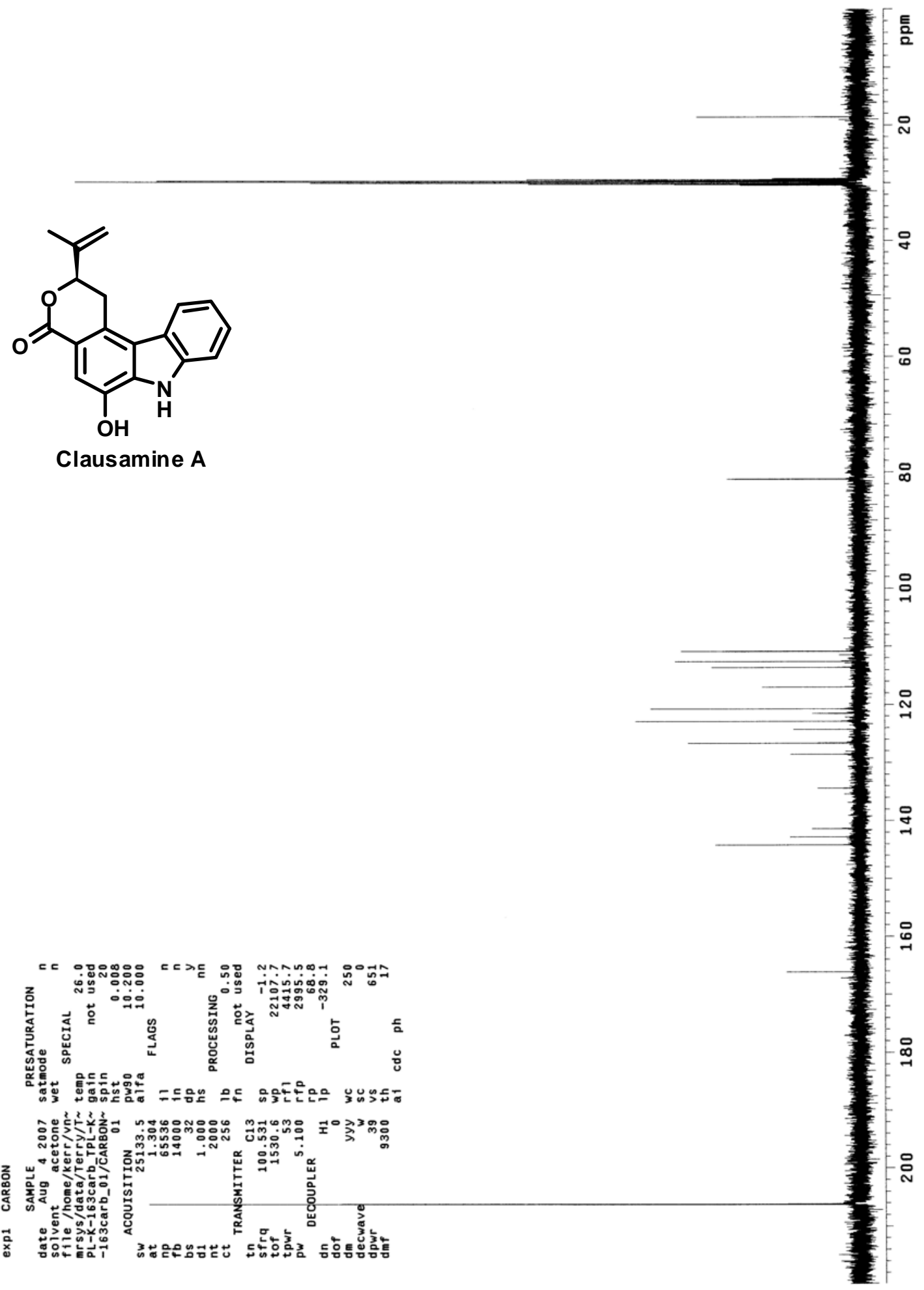




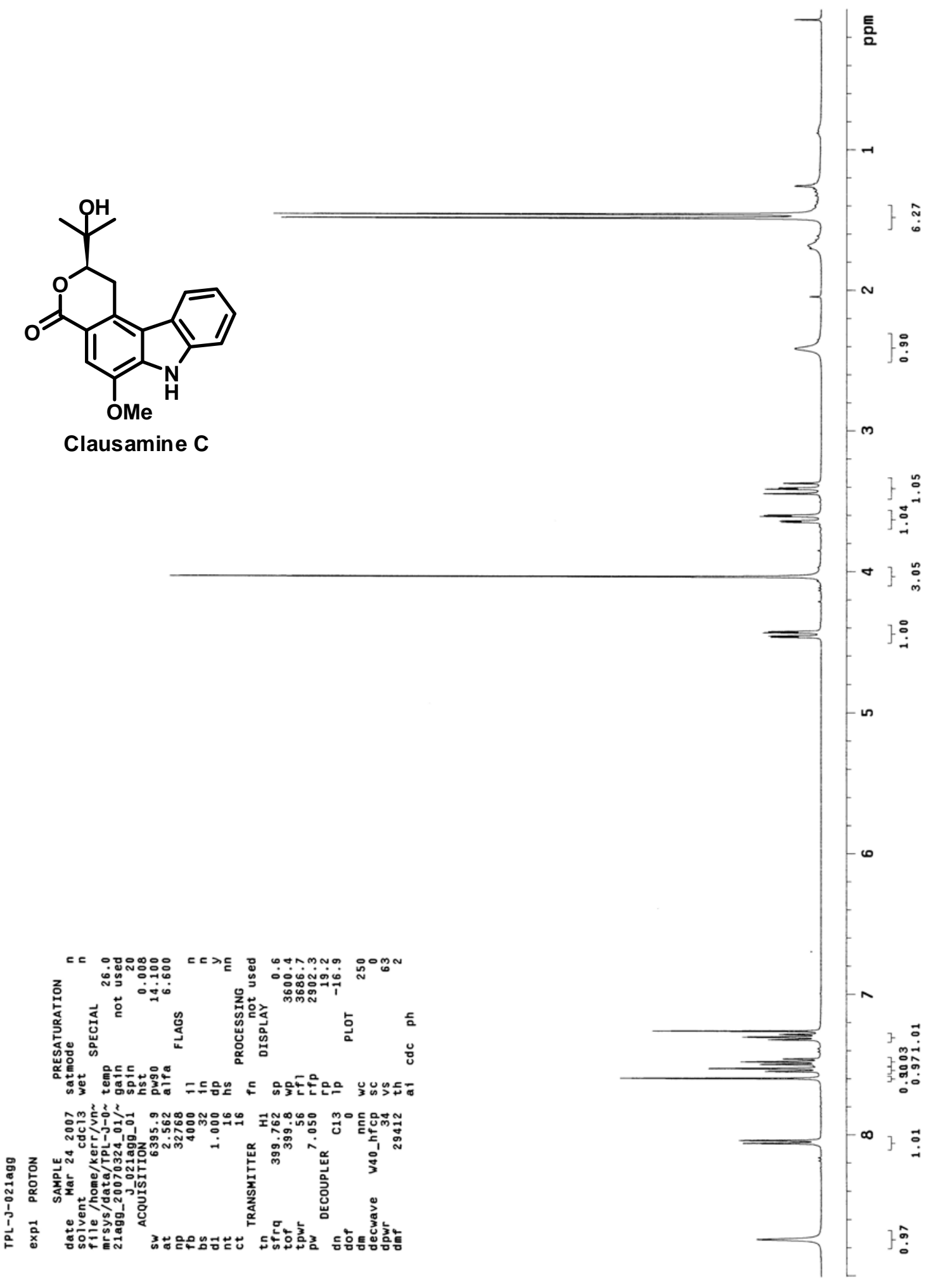


<smiles>COc1cc2c(c3c1[nH]c1ccccc13)CC(C(C)(C)O)OC2=O</smiles>

Clausamine $C$

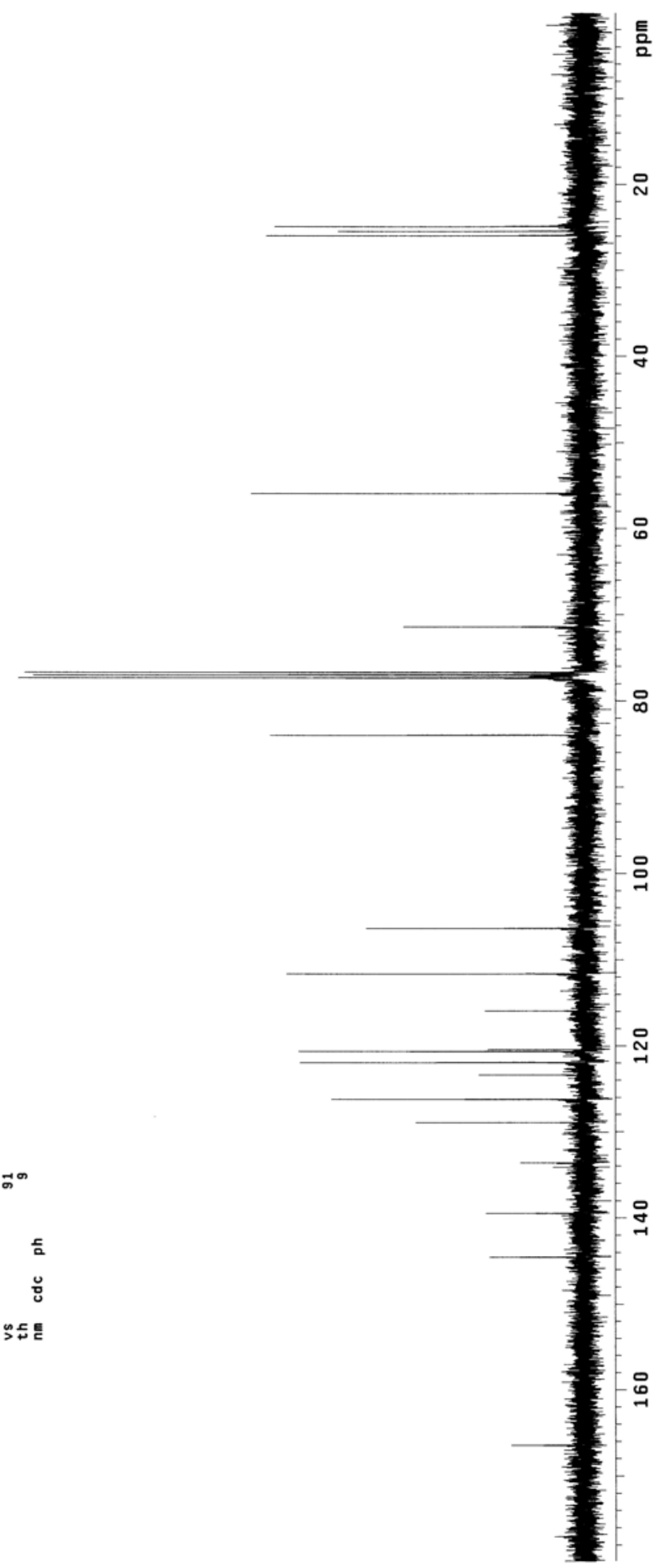




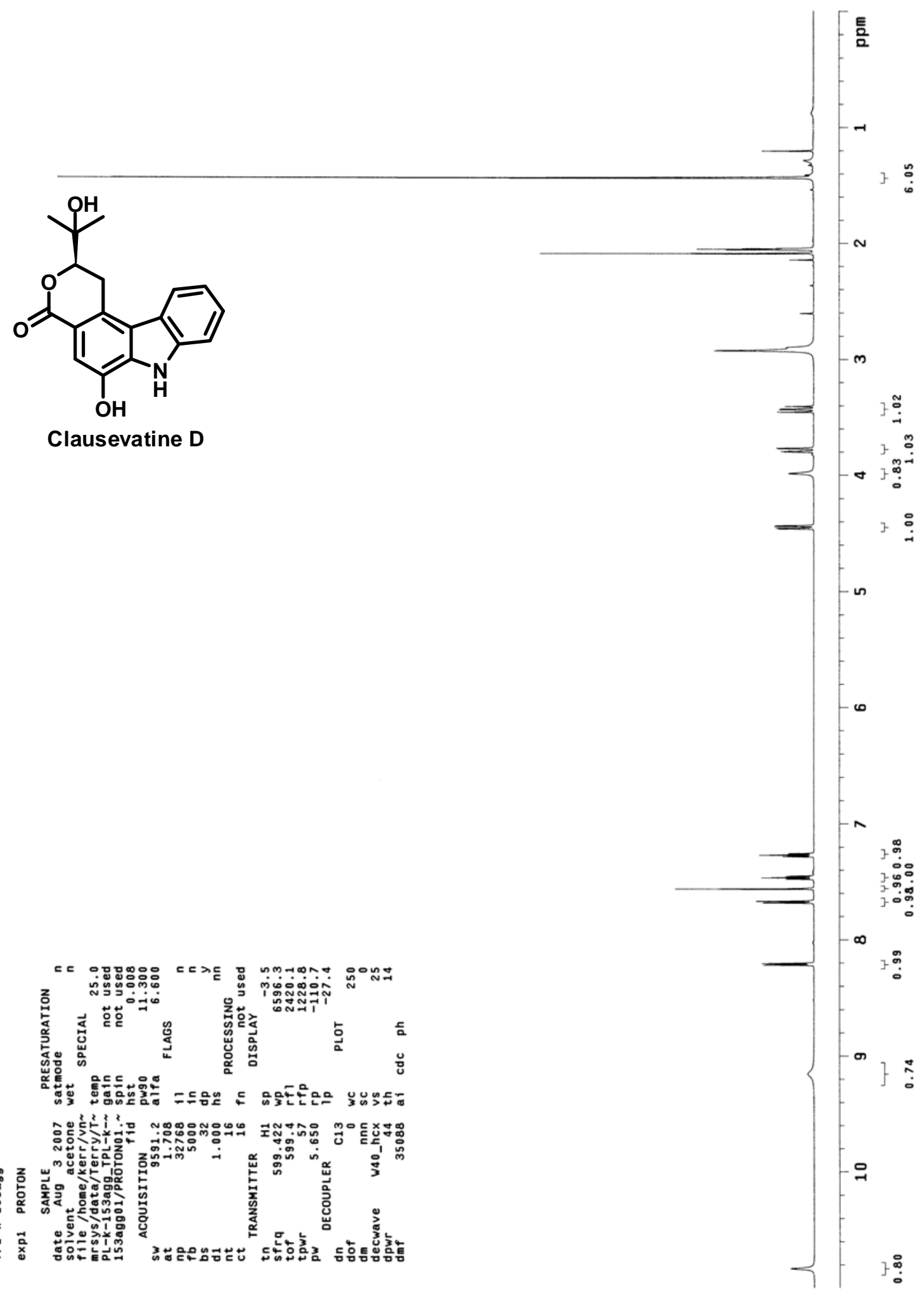




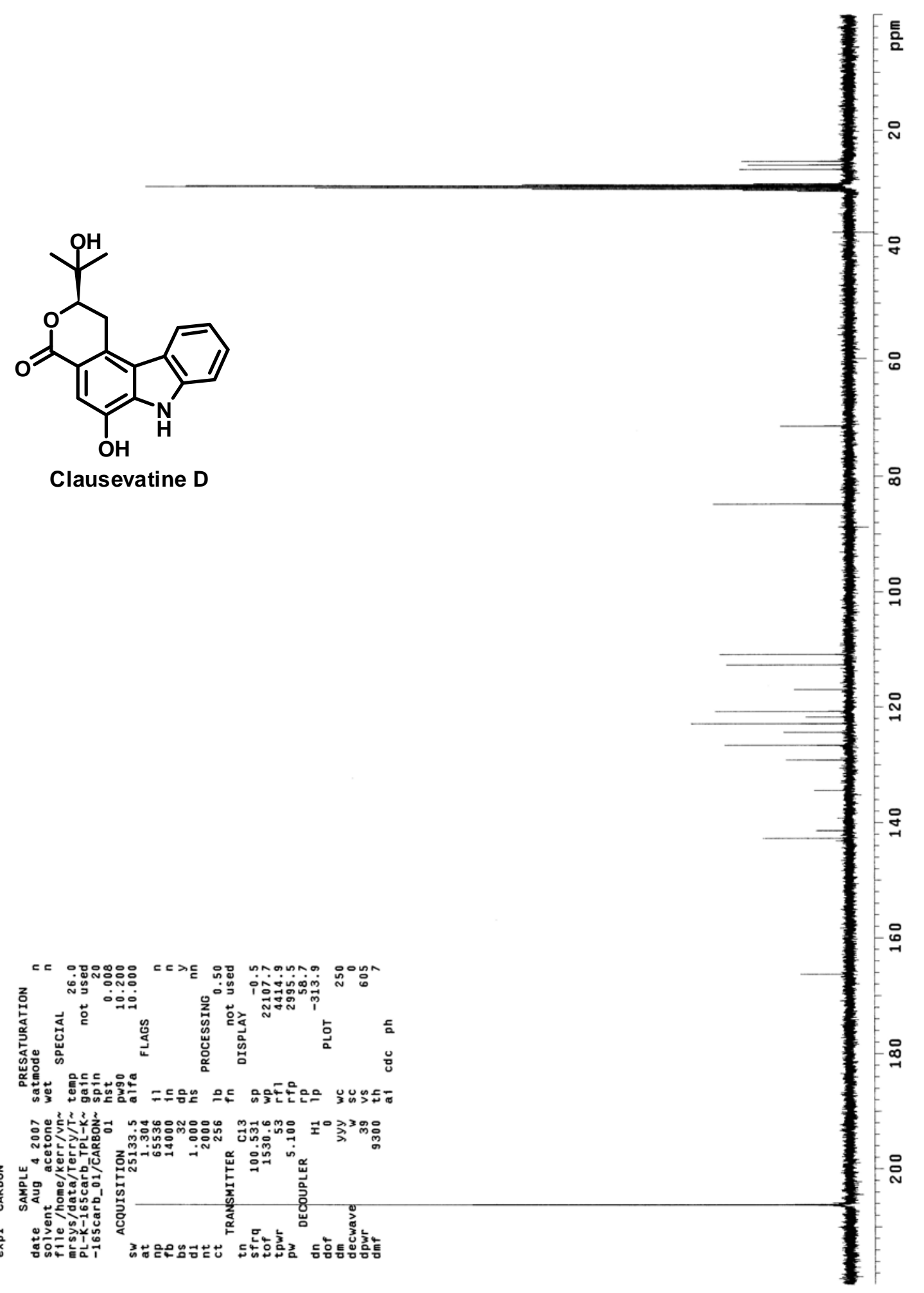

